\title{
Co-expression and Interaction of Cubilin and Megalin in the Adult Male Rat Reproductive System
}

\author{
Oliver Van Praet \\ Department of Anatomy and Cell Biology \\ McGill University, Montreal \\ July 2002
}

A thesis submitted to the Faculty of Graduate Studies and Research

in partial fulfillment of the requirements of the degree of

Master of Science

(C) Oliver Van Praet 2002 
National Library
of Canada

Acquisitions and Bibliographic Services

395 Wellington Street Ottawa ON K1A ON4 Canada
Bibliothèque nationale

du Canada

Acquisisitons et services bibliographiques

395, rue Wellington Ottawa ON K1A ON4 Canada
Yourfile Votre référence

ISBN: 0-612-85835-9

Ourfile Notre référence

ISBN: 0-612-85835-9
The author has granted a nonexclusive licence allowing the National Library of Canada to reproduce, loan, distribute or sell copies of this thesis in microform, paper or electronic formats.

The author retains ownership of the copyright in this thesis. Neither the thesis nor substantial extracts from it may be printed or otherwise reproduced without the author's permission.
L'auteur a accordé une licence non exclusive permettant à la Bibliothèque nationale du Canada de reproduire, prêter, distribuer ou vendre des copies de cette thèse sous la forme de microfiche/film, de reproduction sur papier ou sur format électronique.

L'auteur conserve la propriété du droit d'auteur qui protège cette thèse. $\mathrm{Ni}$ la thèse ni des extraits substantiels de celle-ci ne doivent être imprimés ou aturement reproduits sans son autorisation. 
Short Title: Cubilin and Megalin in the Adult Male Rat Reproductive System 


\begin{abstract}
Cubilin is a peripheral membrane protein that co-operates with the endocytic receptor megalin to mediate the endocytosis of ligands in various polarized epithelia. Megalin is expressed in the male reproductive tract where is has been implicated in the process of sperm membrane remodeling. A potential role for cubilin in the male reproductive tract has not been explored. Using RT-PCR, we found that cubilin and megalin mRNAs are expressed in the efferent ducts, corpus and cauda epididymides, and proximal and distal vas deferens. Immunohistological analysis revealed that cubilin was expressed in nonciliated cells of the efferent ducts, principal cells of the corpus and cauda epididymides and vas deferens. Electron microscopic immunogold labeling showed cubilin in endocytic pits, endocytic vesicles and endosomes of these cells. The expression profile of cubilin in the male reproductive tract was coincident with that of megalin except in principal cells of the caput epididymidis. Double immunogold labeling showed that cubilin and megalin co-localized with one another within the endocytic apparatus and recycling vesicles of efferent duct cells. Neither protein was found in lysosomes. Injection of $\mathrm{RAP}$, an antagonist of megalin interaction with cubilin, reduced the level of intracellular cubilin in cells of the efferent ducts and vas deferens. In conclusion, cubilin and megalin are co-expressed in cells of the epididymis and vas deferens and the endocytosis of cubilin in these tissues is dependent on megalin. Together, these findings highlight the potential for a joint endocytic role for cubilin and megalin in the male reproductive tract.
\end{abstract}




\section{RESUME}

Cubilin est une protéine associée à la membrane cellulaire. Elle co-opère avec le récepteur endocytique megalin en servant de médiateur dans l'endocytose de ligands dans différents épithélia polarisés. Megalin est exprimé cans le système reproducteur du mâle ou il fut impliqué dans le processus de transformation de la membrane cellulaire du sperme. Un rôle potenciel de cubilin dans le système reproducteur mâle n'a pas été exploré. En utilisant le TR-ACP nous avons trouvé que des ARNm de cubilin et de megalin sont exprimés dans les canaux efférents, dans le corps et la queue épididymes et dans les régions proximales et distales du canal déférent. Une analyse immunohistologique a dẻmontré que cubilin était exprimée dans les cellules nonciliées des canaux efférents, dans les cellules principales du corps et de la queue épididyme, ainsi que dans celles du canal déferent. L'analyse immunocytochimique en microscope électronique a démontré la présence de cubilin dans les fosses et les vésicules endocytiques et les endosomes de ces cellules. Dans le système reproducteur du mâle le profil d'expression de cubilin coincidait avec celui de megalin, sauf dans les cellules principales de la tête épididyme. Le double marquage a l'aide d'anticorps liés à l'or colloïdal a revélé que cubilin et megalin étaient co-localisés endeans l'appareil endocytique et les vésicules de recyclage des cellules des canaux efférents. Aucune de ces deux protéines ne figuraient dans les lysosomes. Une injection de RAP, un antagoniste de l'interaction megalin:cubilin, diminua le niveau de cubilin intracellulaire dans les cellules de canaux efférents et déférents. En conclusion, cubilin et megalin sont co-exprimés dans les cellules de l'épididyme et du canal déférent et l' endocytose de cubilin dans ces tissus depend du megalin. L'ensemble de ces recherches démontre la possibilité d'un rôle endocytique co-ordoné de cubilin et megalin dans le système reproducteur du mâle. 
to Vader Loos, who would have enjoyed reading these pages 


\section{ACKNOWLEDGEMENTS}

I would first like to acknowledge the work and efforts of two research project students Jennifer Rattenbury and Sarah Greenwood, who both helped tremendously with some of the initial LM and EM experimentation.

For his precise and helpful technical advice on protein isolation, I thank Ali Fazel. For her guidance and hands on assistance with the RT-PCR, I am forever grateful to Elizabeth Marostica. And for never being to busy to answer my molecular biology queries, I thank the ever-attentive Jibin Zeng.

Jeannie Mui receives my full appreciation for preparing the EM grids, for helping troubleshoot with the electron microscope and for countless other deeds.

Shari Chung, Nadine Korah, Haitham Badran, Stephane Lefrancois and Robert L'Heureux are to be infinitely thanked for assistance, support, friendship and entertainment, but not necessarily in that order.

I thank Dr. Louis Hermo as well as Dr. Marc Pelletier for constructive criticism of my posters and seminars throughout my degree.

And, I shall not forget my parents who, wherever they may have been at any given time, have been fully supportive of (most of) my endeavors. Plus many thanks for the translation.

Finally, I would sincerely like to thank my supervisor, Dr. Carlos Morales, for his guidance, assistance and friendship. It has truly been a pleasure working with you. 


\section{TABLE OF CONTENTS}

Short title.

Abstract....

Resumé

Acknowledgements.

Table of Contents.

I. Introduction

II. Review of the Literature.

A. The adult male rat reproductive tract............................ 4

1. Gross structure........................................ 4

2. The efferent ducts.................................... 5

a. Structure ................................. 5

b. Nonciliated cells............................... 5

c. Ciliated cells................................ 6

d. Function of the efferent ducts.................. 7

3. The epididymis....................................... 7

a. Structure .................................. 7

b. Principal cells............................... 7

c. Narrow cells................................. 8

d. Apical cells................................... 8

e. Clear cells........................................ 9

f. Basal cells.................................... 9

g. Halo cells................................... 10

h. Functions of the epididymis.................... 10

4. The vas deferens........................................ 10

a. Structure.................................... 10

b. Functions of the vas deferens.................... 11

B. Sperm maturation.......................................... 11

1. Ultrastructural changes in sperm maturation............. 12

2. Plasma membrane remodeling.......................... 13

a. Plasma membrane remodeling: proteins........ 13

b. Plasma membrane remodeling: lipids............... 14

C. Apolipoproteins in the male reproductive tract.................. 15

1. Apolipoprotein E...................................... 16

2. Apolipoprotein B.................................... 17

3. Apolipoprotein A-I................................... 17

4. Apolipoprotein J........................................ 18

D. Megalin................................................. 19

1. Megalin, as a member of the LDL receptor superfamily.. $\quad 19$

2. Structure of megalin.................................... 20

3. Distribution and function of megalin..................... 21

4. Megalin in the male reproductive tract................... 22 
E. Cubilin.......................................................... 23

1. Structure of cubilin.................................... 23

2. Cubilin's interaction with megalin....................... 24

3. Distribution of cubilin................................ 25

4. Cubilin's ligands.................................... 25

5. Physiological roles of cubilin.......................... 26

III. Materials and Methods.............................................. 28

A. Antibodies and reagents.................................... 28

B. RNA isolation and RT-PCR................................ 28

C. Immunoblot analysis...................................... 29

D. Immunohistochemical staining .............................. 30

E. Immunogold electron microscopy ............................ 31

F. Injection of efferent ducts and vas deferens.................... 31

IV. Results..................................................... ${ }_{32}$

A. Cubilin and megalin transcripts are co-expressed in male reproductive tract tissues................................... 32

B. Immunoblot and immunocytochemical analysis of cubilin expression in male reproductive tract tissues.................. 33

C. Cubilin traffics with megalin in endocytic compartments........ 34

D. RAP, the antagonist of megalin:cubilin interaction, inhibits cubilin uptake............................................ 34

V. Figures and Tables............................................. 36

VI. Discussion....................................................... 69

VII. Conclusions.................................................. 74

VIII. Abbreviations................................................... $\quad 75$

IX. References.............................................. 77 


\section{INTRODUCTION}

A newly formed spermatozoon, just released into the lumen of the seminiferous tubules, is functionally immature, i.e., immobile and incapable of fertilization. As it progresses through the efferent ducts, epididymis and vas deferens, it encounters a host of luminal proteins, some of which are thought to mediate a series of structural and biochemical changes on the spermatozoon. These changes are in turn believed to contribute to the acquisition of fertilization capability (reviewed in Dacheux et al., 1998; Holland and Nixon, 1998; Cooper, 1998; Hermo et al., 1994). In particular, there has been much focus on the remodeling of the spermatozoon plasma membrane. Across most species, a selective reduction of phospholipid content and a rearrangement of the cholesterol in the various domains of its plasma membrane occurs during its epididymal transit (reviewed in Jones, 1998). This, along with subsequent postejaculatory reduction in membrane cholesterol during capacitation, appears to be essential in establishing acrosomal responsiveness and fertilizing capacity (reviewed in Cross, 1998).

Candidate proteins involved in the rearrangement and traffic of these lipids to and from the sperm membrane includes apolipoprotein J (apo J/SGP-2/clusterin), a soluble lipid-binding protein found to be associated with high density lipoproteins (HDL) in human plasma, specifically with the subclasses of HDL that also contain apo A-I (de Silva et al., 1990). Apo J is the main secretory product of the Sertoli cell and has been shown to bind to the sperm plasma membrane (Sylvester et al., 1991). Once its postulated task of transferring lipids is complete, apo $J$ is taken up into the endocytic 
apparatus of the epithelial cells lining the efferent ducts and epididymis for lysosomal degradation (Hermo et al., 1991; Igdoura et al., 1994). This reuptake is mediated by megalin (also known as low density lipoprotein receptor-related protein-2 or LRP-2), an epithelial endocytic receptor in the male rat reproductive system (Morales et al., 1996).

Recently, it has been found that cubilin, a 460kDa membrane-associated epithelial receptor, co-localizes with megalin in various absorptive epithelia - including the kidney proximal tubule, ileum and lung (reviewed in Moestrup and Verroust, 2001). Megalin and cubilin are both large multiligand receptors involved in receptor-mediated endocytosis of protein-bound lipids, vitamins and hormones. While megalin is a typical endocytic receptor with a transmembrane domain and three consensus cytoplasmic motifs for binding adaptor proteins and clathrin, cubilin is membrane-associated but lacks a transmembrane domain and its internalization is accomplished by backpacking on megalin (Saito et al., 1994; Moestrup et al., 1998). Several lines of in vitro evidence, including cell culture and indirect analyses of knock out animals, have been used to suggest that megalin and cubilin interact functionally in vivo (Burmeister et al., 2001; Kozyraki et al., 2001; Hammad et al., 2000; Nykjaer et al., 2001; Zhai et al., 2000; Hammad et al., 1999).

Since cubilin and megalin co-localize in virtually every tissue investigated and since cubilin is the receptor for lipid binding-proteins (specifically apo A-I) it is therefore an additional candidate in the process of sperm membrane remodeling (Moestrop et al., 
2001; Kozyraki et al., 1999). As such, our first objective of this research was to determine the expression and distribution of cubilin in the male reproductive tract. Then, using the male reproductive system as a model in vivo system, the subcellular localization of cubilin and megalin were compared. Finally, using the same in vivo system, the cubilin:megalin interaction was blocked to determine whether a direct interaction occurs between the two receptors in the male reproductive tract. 


\section{REVIEW OF THE LITERATURE}

The present study is concerned with the maturation of spermatozoa in the efferent ducts, epididymis and vas deferens of the adult male rat. More specifically, two endocytic receptors - megalin and cubilin - are here examined as potential players in this process of sperm development. Therefore, we will begin by examining the literature on the histology of the efferent ducts, epididymis and vas deferens. We will then look at the process of sperm maturation in the lumen of these segments of the male reproductive tract. The possible role of apolipoproteins in this process will be discussed. We will then turn our focus to megalin and examine its structure and function in both the male reproductive system and in other tissues. Finally we will discuss the structure, function and distribution of cubilin and its interaction with megalin.

\section{A. The adult male rat reproductive tract}

\section{Gross structure}

The adult male rat reproductive tract is divided into several anatomically and histologically distinct regions. Spermatozoa are produced in the seminiferous epithelium lining the hundreds of highly tortuous seminiferous tubules in the testis. These tortuous tubules all connect to a series of short straight tubules, the tubili recti, which then connect to a labyrinthine space, the rete testis (Ilio and Hess, 1994). Near the testicular margin, approximately six or seven efferent ducts arise independently from the rete tesits (Jones and Jurd, 1987). These efferent ducts pierce the fibromuscular connective tissue capsule of the testis - the tunica albuginea - and become embedded in the superior epididymal ligament. The efferent ducts can be divided into three regions: the initial zone, in which there are six distinct ducts; the coni vasculi, in which the ducts anastomose and funnel into a single tubule; and the terminal zone, that abruptly changes into the initial segment of the epididymis (Cooper and Jackson, 1972). The epididymis, which is composed of a single highly convoluted tubule, is itself divided into five segments: the initial segment, 
the intermediate zone, the caput epididymidis, the corpus epididymidis and the cauda epididymidis (Robaire and Hermo 1988). Emerging from the cauda epididymidis, the tubule straightens, becomes enveloped in a thick layer of smooth muscle and is named the vas deferens (Hermo et al., 2002). The vas deferens eventually connects with the urethra, which progresses through the penis and leads to the outside of the body.

\section{The efferent ducts}

\section{a. Structure}

Viewed under the light microscope, the simple columnar epithelium of the efferent ducts appears festooned. The apical aspect of the epithelium faces the lumen of the duct while a thin layer of smooth muscle and connective tissue supports the basal aspect (Ilio and Hess, 1994). The epithelium is mainly composed of ciliated and nonciliated cells but there are also occasional halo cells found interspersed (Robaire and Hermo, 1988).

\section{b. Nonciliated cells}

The nonciliated cells are the most predominant cells in the efferent ducts. They are columnar, with a brush border of microvilli and a round, pale, basally located nucleus (Robaire and Hermo, 1988). The supranuclear region is filled with numerous granules that are moderately stained in the initial zone while being more darkly stained and significantly more voluminous in the terminal zone (Jones and Jurd, 1987, Robaire and Hermo, 1988). Electron microscopy reveals the ultrastructural details of three distinct cytoplasmic divisions of the nonciliated cells. The apical region contains cisternae of endoplasmic reticulum, mitochondria; the supranuclear region contains Golgi stacks and more ER cisternae; and the basal region contains the nucleus and many lipid droplets (Hermo and Morales, 1984). In addition to the presence of these organelles, the three cytoplasmic regions are also defined by the various vesicles and organelles which form the substantial endocytic apparatus in these cells. Nonciliated cells are highly endocytic and are effective in performing both fluid phase and adsorptive endocytosis (Hermo and Morales, 1984). In the apical region, forming large dilated invaginations between microvilli, are tubular coated pits. These pits pinch off and give rise to a population of 
apical tubules which are found immediately beneath the cell surface. These tubules give rise, in turn, to large dilated membranous vacuoles, or endosomes, with an electron-lucent matrix. Still in the apical aspect, several multivesicular bodies (also known as late endosomes), with a variably staining matrix, are found surrounded by a number of small vesicles (Robaire and Hermo, 1988). Pulse chase experiments suggest that the variable luminal staining of the multivesicular bodies - from paler to denser - represents their progression along the endocytic pathway (Hermo and Morales, 1984; Hermo et al., 1994). This progression continues through to the aforementioned supranuclear granules, which, under the electron microscope, are large membrane-bound bodies that have been cytochemically identified as lysosomes (Hermo and Morales, 1984). A few lysosomes are also found basally and some of these are found in close association with lipid droplets. These lipid droplets are thought to be the end products of the digested material taken up by the nonciliated cells (Ilio and Hess, 1994; Hermo and Morales, 1984).

Several notable proteins are endocytosed by the nonciliated cells, including sulfated glycoprotein-1 (SGP-1), SGP-2 (also known as clusterin or apolipoprotein J), androgen binding protein and transferrin (Igdoura et al., 1993; Hermo et al., 1991a; Pelliniemi et al, 1981; Veeramachaneni and Amann, 1991).

The Golgi apparatus of the nonciliated cells shows no evidence of secretory granule formation, therefore these cells do not appear to be secretory in nature (Rambourg et al., 1987).

\section{c. Ciliated cells}

The ciliated cells of the efferent ducts are also tall columnar cells but are less numerous than the nonciliated cells. Through the initial zone and coni vasculosus, they number 1 for every 5 nonciliated cells and increase to 1 for every 2 nonciliated cells in the terminal zone (Jones and Jurd, 1987). The ciliated cells are deeper staining than their nonciliated neighbors, their nuclei are located apically, they have an abundance of mitochondria and as their name would suggest, they have long apical cilia (Robaire and Hermo, 1988). These cilia seem to function in stirring the luminal fluid, rather than in 
sperm propulsion (Klinefelter and Hess, 1998). The ciliated cells also appear to be involved in fluid-phase and adsorptive endocytosis. They contain all of the same endocytic components as nonciliated cells, simply less numerous and more scattered about the cytoplasm (Hermo et al., 1985).

\section{d. Function of the efferent ducts}

It is commonly accepted that fluid reabsorption is the main function of the efferent ducts. Various physiological experiments have demonstrated that most of the fluid leaving the testis is resorbed by the efferent ducts, thereby significantly increasing the sperm concentration in the lumen (Jones and Jurd, 1987; Levine and Marsh, 1971; Clulow et al., 1998). The fluid transport occurs via numerous mechanisms including active solute transport, passive permeability and fluid phase endocytosis (Clulow et al., 1998).

\section{The epididymis}

\section{a. Structure}

The five epididymal regions - initial segment, intermediate zone, caput, corpus and cauda - are each defined by a unique histological appearance and subset of cell types. In the proximal regions of the epididymis, the epithelium is composed of tall columnar cells surrounding a narrow lumen. Progressing down the epididymal epithelium, the luminal diameter increases while cell height decreases, finally reaching a low cuboidal state in the cauda (Reid and Cleland, 1957). Several cell types make up the epididymal epithelium including principal, narrow, apical, clear, basal and halo cells (Hermo and Robaire, 2002).

\section{b. Principal cells}

The epididymal principal cells differ morphologically and functionally from region to region down the epididymis (Robaire and Hermo, 1988). The principal cells in the initial segment, which comprise $80 \%$ of the epithelial cells, are columnar, mildly staining and are topped by a few microvilli forming a brush boarder. The mid-basal nuclei are round, 
pale staining, with a distinct nucleolus and a few supranuclear lysosomes (Robaire and Hermo, 1988). In the remainder of the epididymis, where their relative number gradually decreases to about $65 \%$, the principal cells are mildly stained and have a pronounced apical brush boarder (Robaire and Hermo, 1988). Their nuclei are irregular in shape with a well-defined nucleolus and many supranuclear lysosomes (Robaire and Hermo, 1988).

Principal cells are active in protein synthesis and merocrine secretion as well as in endocytosis. The Golgi apparatus is well developed and associated with smooth surfaced vesicles on the trans face which have been shown to correspond to secretory granules (Hermo et al., 1991a; 1991b; 1994). The endocytic apparatus consists of the sequential series of coated pits, coated vesicles, endosomes, pale and dense multivesicular bodies (or late endosomes) and lysosomes (Hermo et al., 1994). There are also a series of tubules emanating from endosomes which function in recycling receptors back to the cell surface (Hermo et al., 1994).

c. Narrow cells

Narrow cells are limited to the initial segment and intermediate zone (Sun and Flickinger, 1980; Adamali and Hermo, 1996). They make up about 3\% of the cells in the initial segment and about $6 \%$ in the intermediate zone (Adamali and Hermo, 1996). They are characteristically narrower than the principal cells, have an apical nucleus, numerous apical endocytic vesicles and many mitochondria with tubular cristae (Sun and Flickinger, 1980). In addition to a distinct morphological appearance, narrow cells express a different set of proteins than their neighboring epithelial cells (Adamali and Hermo, 1996).

\section{d. Apical cells}

Apical cells are likewise limited to the initial segment and intermediate zone, comprising about $11 \%$ of the cells in the former region but only just over $1 \%$ in the latter (Sun and Flickinger, 1980; Adamali and Hermo, 1996). Apical cells are goblet shaped, have an apically-located round nucleus and do not contact the basement membrane (Adamali and Hermo, 1996; Hermo and Robaire, 2002). Apical cells also express a 
unique protein profile that differentiates them from the other epithelial cells (Hermo and Robaire, 2002).

\section{e. Clear cells}

Clear cells are located in the caput, corpus and cauda epididymidis and make up 5\%, $8 \%$ and $10 \%$ of the cells in each region, respectively (Robaire and Hermo, 1988). They are identified by their elaborate endocytic machinery and many lysosomes surrounding the round, pale-staining, basally-located nucleus (Robaire and Hermo, 1988; Hermo and Robaire, 2002). Notably, caudal clear cells actively endocytose the cytoplasmic droplets released by the spermatozoa as they pass through this final region of the epididymis (Hermo et al., 1988). In addition, the clear cells actively endocytose many other luminal proteins including metalloproteins and immobilin (Vierula et al., 1995; Hermo et al., 1992).

\section{f. Basal cells}

As their name suggests, basal cells adhere to the basement membrane and extend towards, but do not reach, the lumen of the duct (Hamilton, 1975). They are located throughout the epididymis and their long, thin processes cover a large portion of the basement membrane of the duct (Robaire and Hermo, 1988; Veri et al., 1993). They are hemispherical in shape and possess a round or elongated, moderately staining nucleus. Progressing down the epididymis, their relative proportion increases from $12 \%$ in the initial segment and caput epididymidis to $21 \%$ in the corpus and cauda epididymidis (Robaire and Hermo, 1988). Coated pits line the basal aspect facing the basement membrane as well as the apical aspect facing adjacent cells, suggesting the basal cells are actively endocytosing both blood factors and principal cell factors (Robaire and Hermo, 1988). Furthermore, the presence of secretory granules also suggest a role in protein secretion (Hermo and Robaire, 2002). It should also be noted that basal cells are not stem cells (Clermont and Flannery, 1970). 


\section{g. Halo cells}

The final epididymal cell type is the halo cell, found throughout the epididymal epithelium and, depending on the region, makes up between $4-6 \%$ of the epithelial cells (Robaire and Hermo, 1988). These small cells are usually located basally and only have a small amount of cytoplasm surrounding their dense nucleus. Halo cells are the primary immune cells in the epididymis and have been recently identified as helper $T$ lymphocytes, cytotoxic T lymphocytes and monocytes (Flickinger et al., 1997; Serre and Robaire, 1999).

h. Functions of the epididymis

The epididymis is involved in providing a series of changing microenvironments in which the spermatozoa bathe and which mediate sperm maturation. Various cell types in different regions of the epididymis selectively secrete and endocytose of a variety of luminal factors to create these epididymal microenvironments (Hermo et al., 1994). In addition to secretion and endocytosis, the luminal environment is also regionally regulated with respect to ion and water content. Ion transporters (such as carbonic anhydrase II and vacuolar proton adenosine triphosphatase) and water channels (including aquaporins 6 and 9) appear to be essential in maintaining the ionic and $\mathrm{pH}$ levels of the epididymal fluid (Hermo et al, 2000; Hermo and Robaire, 2002; Badran and Hermo, 2002). Furthermore, epithelial cells of the epididymis have an additional function in protecting the spermatozoa from oxidative damage and foreign attack. An array of glutathione S-transferase (GST) subunits act throughout the epididymis to protect against electrophilic attack while the halo cells are thought to provide and immunological barrier in the epithelium (Veri et al., 1993; Andonian and Hermo, 1999a; Adamali and Hermo, 1996; Flickinger et al., 1997; Hooper et al., 1995).

\section{The vas deferens}

a. Structure

The epithelium of the proximal vas deferens resembles that of the cauda epididymidis in that it is cuboidal and contains principal, clear, basal and halo cells (Robaire and 
Hermo, 1988). The lumen is distended and filled with sperm and a thin muscular wall surrounds the epithelium. Progressing toward the middle and then distal vas deferens, the epithelium gradually becomes tall columnar, the microvilli of the principal cells elongate dramatically and the clear and narrow cells disappear (Kennedy and Heidger, 1979; Hermo et al., 2002). The muscular wall thickens and the lumen gradually becomes more convoluted and less filled with sperm (Kennedy and Heidger, 1979).

b. Functions of the vas deferens

Although the vas deferens is often thought to be a simple conduit for sperm, there has been increasing evidence suggesting that the cauda epididymidal roles of sperm storage and participation in sperm maturation are also exhibited in the vas deferens (Hermo et al., 2002). Principal cells in the vas deferens demonstrate a well developed secretory apparatus with a rough endoplasmic reticulum, a Golgi apparatus and secretory vesicles suggesting an active mechanism for merocrine secretion (Hamilton, 1975; Robaire and Hermo, 1988). Interestingly, in the vas deferens, there is also evidence for apocrine secretion through apical blebs, which protrude between the microvilli, increase in size and eventually detach from the cell surface to release their cytoplasmic contents into the lumen (Andonian and Hermo, 1999b). Furthermore, principal cells are also endocytic and have all the necessary machinery to accomplish this function (Hermo and de Melo, 1987). Also, just as in the epididymis, the vas deferens utilizes aquaporins, vacuolar proton-pumping ATPase and GST subunits for luminal fluid ionic balance and for sperm protection (Brown et al., 1993; Hermo et al., 2002; Brown and Breton, 2000; Andonian and Hermo, 1999a).

\section{B. Sperm maturation}

As spermatozoa exit the testis they are still immature. They have not yet acquired their motility and they are unable to recognize or fertilize an ovum. Progressing through the epididymis and vas deferens, spermatozoa pass through a progressively changing series of microenvironments which are created by regionally dictated secretory and 
absorptive activities (Hinton and Palladino, 1995). These changing microenvironments mediate a series of ultrastructural and biochemical alterations of the spermatozoa which occur concomitantly with the progressive acquisition of motility and fertilizing ability (Jones, 1998).

\section{Ultrastructural changes in sperm maturation}

The greatest ultrastructural changes in the developing gamete occur during spermiogenesis as the round spermatid develops into a spermatozoon in the seminiferous tubules of the testis. However, even after spermiation, this structural maturation continues in the efferent ducts, epididymis and vas deferens. Firstly, the acrosome - a membrane bound organelle containing various hydrolytic enzymes which are released during fertilization and which digest the zona pellucida of the oocyte - continues to change morphologically with its most apical segment becoming significantly shorter (Olson et al., 2002). Also, the proteins comprising the acrosomal matrix undergo positional reorganization and the soluble acrosomal enzymes undergo biochemical alterations (Yoshinaga et al., 1998; Westbrook-Case et al., 1995; Lakoski et al., 1988; NagDas et al., 1992). Furthermore, within the nucleus, the matrix fibers increase in density in a process that is thought to be associated with chromatin condensation (Cheng-Chew et al., 1994). Likewise, several cytoskeletal elements of the spermatozoa, including the perinuclear theca, the connecting piece, the outer dense fibers and the fibrous sheath, become more condensed and increasingly cross-linked by stabilizing disulfide bonds (Bedford and Nicander, 1971; Bedford and Calvin, 1974a; 1974b). Finally and perhaps most dramatically, an expansion of the cytoplasm, called the cytoplasmic droplet, migrates from the neck region to the distal end of the midpiece and eventually detaches from the tail (Oko et al., 1993). In addition to trimming excess cytoplasm from the spermatozoa, this cytoplasmic droplet has also been implicated in plasma membrane remodeling, particularly with respect to recruiting cytosolic proteins to the midpiece plasma membrane (Olson et al., 1997). 


\section{Plasma membrane remodeling}

Indeed, the most important post-testicular biochemical alterations of the spermatozoon are the complex processes of plasma membrane remodeling (a small part of which may include modifications due to the cytoplasmic droplet). Because the sperm plasma membrane must withstand the varying conditions proffered by both the male and female genital tracts, because it must be specialized enough to mediate the process of fertilization and because the composition of this membrane is dramatically altered in its epididymal transit, much attention in spermatozoa maturation has focused on the intricate events of plasma membrane remodeling.

The plasma membrane of the maturing spermatozoa, like that of somatic cells, contains proteins, lipids, glycolipids and glycoproteins arranged in a typical bilayer. However, it is somewhat unique in that the lipids and proteins are highly compartmentalized to distinct regions within the head and tail (Jones, 2002). Most posttesticular plasma membrane alterations are not only highly specific with regards to particular proteins and lipids, but also with respect to these different regions of the plasma membrane itself.

a. Plasma membrane remodeling: proteins

Many novel proteins which are absent from testicular spermatozoa are present in the plasma membranes of ejaculated sperm. Because there is no de novo protein synthesis in a spermatozoon, these proteins must arise from the surrounding luminal fluid. The epithelial cells lining the efferent ducts, epididymis and vas deferens secrete a number of soluble proteins which are taken up by the sperm plasma membrane either through hydrophobic interactions with the bilayer lipids, through catalyzed crosslinking of proteins or by interacting with membrane receptors (Jones, 2002). For example, proteins destined to the periacrosomal plasma membrane may be part of an amorphous electron dense material in the epididymal lumen which specifically yet transiently binds this region of the plasma membrane in the caput and corpus epididymidis (Suzuki and Nagano, 1980). Also, membranous vesicles called prostasomes are thought to transport 
GPI-anchored proteins from the surrounding epithelium to the spermatozoa (Kirchhoff, 1998; Legare et al., 1999). But, although there is a significant number of novel proteins brought to the sperm plasma membrane through these mechanisms, quantitatively there is a net reduction in both integral and membrane bound proteins through the transit (Jones et al., 1983). In fact, the total plasma membrane protein content decreases from $79 \mathrm{mg}$ protein $/ 10^{9}$ sperm in the caput to $20 \mathrm{mg} / 10^{9}$ in the cauda (Hall et al., 1991). Finally, in addition to this concurrent protein accumulation and elimination, there is also a redistribution of integral membrane proteins between specific plasma membrane domains. This reorganization may result from the changing bilayer fluidity; altered interactions between neighboring proteins and/or altered interactions between proteins and the surrounding glycocalyx or cystoskeleton (Suzuki, 1981; Olson et al., 2002).

b. Plasma membrane remodeling: lipids

The lipid components of the plasma membrane also undergo significant post-testicular remodeling. In fact, there is a $54 \%$ decrease in the total membrane phospholipid content from caput to corpus epididymidis (Aveldano et al., 1992). While all phospholipids show a decrease, those found predominantly in the inner leaflet (phosphatidylethanolamine, phosphatidylserine, phosphatidylinositol and ethanolamine plasmalogen) show a much greater decrease than those found predominantly on the outer leaflet (phosphatidylcholine, choline plasmalogen and sphingomyelin) which remain relatively stable (Aveldano et al., 1992; Parks and Hammerstedt, 1985). The result of this is that the sperm plasma membrane, which already contains an unusually high proportion of polyunsaturated phospholipids from the outset, acquires and even greater degree of unsaturation as the sperm matures. The cholesterol content in the rat spermatozoon also declines by over $50 \%$ in its epididymal transit, with an accompanying decrease in the cholesterol:phospholipid ratio from 0.28 to 0.17 (Aveldano et al., 1992). Together, the decreasing saturated:unsaturated fatty acid and cholesterol:phospholipid ratios suggest that the plasma membrane becomes more fluid in its maturation. This, along with a changing density and arrangement of filipin-cholesterol complexes, influences the bilayer stability as well as the lateral diffusion of molecules within it (Jones, 2002). Decreasing cholesterol content is significant because it is a major feature of the capacitation process 
and leads to the activation of downstream signaling protein kinases (Visconti et al., 1999). Furthermore, it has been suggested that that localized areas of cholesterol depletion may be the focal points of membrane fusion in the acrosome reaction (Jones, 2002).

The destination of the departing inner leaflet phospholipids and membrane cholesterol remains uncertain. A long standing notion has been that the phospholipids could be internalized into the cytoplasm to provide fuel for the maturing spermatozoon. Alternatively, it has been widely suggested that the phospholipids and/or the cholesterol may be taken up by lipid-exchange proteins in the epididymal lumen (Jones, 2002). Several candidate lipid-exchangers have been proposed, including apolipoproteins A-I, B, $E$ and $J$ which are all found in the male reproductive tract.

\section{Apolipoproteins in the male reproductive tract}

Lipoproteins are the blood plasma carriers of complex lipids. They include, from largest and least dense to smallest and most dense: chylomicrons, very low density lipoproteins (VLDL), intermediate density lipoproteins (IDL), low density lipoproteins (LDL) and high density lipoproteins (HDL). Chylomicrons serve as the mode of transport of intestinally-absorbed triacylglycerol and cholesterol to the other tissues in the body. VLDL, IDL and LDL transport triacylglycerol and cholesterol from the liver to other tissues. HDL, which is colloquially referred to as the "good-cholesterol", is involved in reverse cholesterol transport of excess plasma membrane cholesterol from peripheral cells to the liver for excretion, catabolism and storage (Mahley et al., 1984). The general structure of all lipoproteins includes a hydrophobic core composed of triacylglycerol and cholesterol ester surrounded by a shell of amphipathic phospholipids, cholesterol and proteins. The surface proteins, called apolipoproteins, provide structural integrity, activate or inhibit lipoprotein modifying enzymes and are the ligands for a large spectrum of receptors and membrane-docking proteins (Willnow, 1999). There are several apolipoproteins which are each associated with a different set of lipoproteins. For 
example, apolipoprotein $\mathrm{C}-\mathrm{I}$ (apo C-I) is found in chylomicrons, VLDL, IDL and HDL while apo D is restricted to HDL (Zubay, 1993).

In the excurrent duct system of the male reproductive tract there are no typical lipoprotein complexes, however four apolipoproteins - E, B, A-I, and J - are present. Much is known about each of these proteins as plasma lipoprotein constituents, but their role in the reproductive tract remains speculative.

\section{Apolipoprotein E}

In the blood plasma, apo $\mathrm{E}$ is associated with chylomicrons, VLDL, IDL and HDL and mediates binding of these lipoproteins to every member of the LDL receptor family (this receptor family will be later discussed in greater detail) (Hussain, 2001). Apo $\mathrm{E}$ is ubiquitously expressed and plays a major role in the redistribution of lipids between tissues and also among different cells within a tissue (Boyles et al, 1989). Normal levels and function of apo $\mathrm{E}$ are essential for protecting against vascular diseases and late onset Alzheimer's disease (Rall et al., 1989; Corder et al., 1993). Apo $\mathrm{E}$ has also been implicated in the induction of several signal transduction pathways through its interaction with cell surface receptors including the inhibition of steroidogenesis in adrenal tumor cells, the inhibition of androgen production by ovarian thecal cells and the modulation of lymphocyte immune responses (Reyland et al., 1991; Dyer and Curtiss, 1988; Avila et al., 1982).

In the male reproductive tract, apo $\mathrm{E}$ has been localized to the Leydig cells of the testis as well as the basal aspect of the epithelium in the caput, corpus and cauda epididymidis (Law et al., 1997). In the testis it is speculated that apo $\mathrm{E}$ is participates in delivering plasma-derived lipoprotein cholesterol to Sertoli cells for sperm membrane biosynthesis. In the epididymis, it is thought that apo $\mathrm{E}$ is involved in removing excess cholesterol or lipid complexes from the basal aspect of the epithelium into the blood stream for further processing (Olson et al., 1995). 


\section{Apolipoprotein B}

The apolipoprotein B gene actually yields two proteins - apo B-100 and apo B-48 resulting from alternate mRNA splicing (Chen et al., 1987; Powell et al., 1987). Hepatocytes incorporate the apo B-100 isoform into triglyceride-rich VLDL particles that become secreted into the blood plasma. IDL and LDL are the metabolic products of VLDL and both of these also contain apo B-100. In fact, apo B-100 is the only apolipoprotein of LDL and serves as the ligand for the LDL receptor-mediated and megalin-mediated uptake of LDL particles by the liver and extrahepatic tissues (Young, 1990; Kesaniemi et al., 1983; Stefansson et a1., 1995). Intestinal enterocytes edit a single nucleotide of the apo B mRNA, which translates to a significantly shorter protein, apo B48, to become incorporated in chylomicrons (Chen et al., 1987; Powell et al., 1987). Apolipoprotein B has been of particular interest because elevated plasma apo B-100 levels are correlated with the development of premature atherosclerotic disease (Sniderman et al., 1980; Teng et al., 1983). Apo B knockouts are embryonic lethals with neural tube defects but the null allele heterozygotes show reduced cholesterol levels and yield infertile males (Huang et al., 1995). In these heterozygotes, the spermatozoa have reduced motility, survivability and penetration of the zona pellucida (Huang et al., 1996). Further investigation has shown that apo $\mathrm{B}$ mRNA is detectable in the testis and the epididymis of normal rodents and at much lower levels in the heterozygotes for the null allele (Huang et al., 1996). The cause of the abnormal sperm in the null allele heterozygote has not yet been definitively linked to either plasma or reproductive apo $B$ levels, but the importance of apo B for normal sperm development is certain.

\section{Apolipoprotein A-I}

Apo A-I has also been localized to the epididymis by northern blot analysis (Law et al., 1997). In the blood plasma, apo A-I is the major constituent of HDL, which performs the process of reverse cholesterol transport. This process begins with small apo A-Icontaining particles in the interstitial fluid which, through their amphipathic helices, interact with the bilayer lipids of the surrounding cells. This binding promotes the efflux 
of cellular cholesterol - either by passive desorption of membrane cholesterol or by the recruitment of membrane proteins to stimulate the translocation of intracellular cholesterol to the plasma membrane. The nascent HDL complex then takes up the exiting cholesterol and, after many such bilayer interactions, transports the cholesterol to the liver (Frank and Marcel, 2000). In the epididymal lumen, a similar process of cholesterol uptake from the sperm plasma membrane by apo A-I-containing particles is suggested to occur, although no mechanistic evidence exists to date (Law et al, 1997).

\section{Apolipoprotein J}

In the blood plasma, apo J (also known as SGP-2 and clusterin) is associated with apo A-I-containing HDL particles and has therefore been implicated in the regulation of lipid transport and local lipid distribution (de Silva et al., 1990; Jenne et al., 1991). Other functions have also been attributed to apo J, including a strong inhibitory activity of the terminal complement cascade (McDonald and Nelsestuen, 1997). Interestingly, apo J has also been found associated with amyloid beta peptide deposits in Alzheimer's disease in conjunction with apolipoprotein $\mathrm{E}$ (Choi-Miura et al., 1992). Apo J is constitutively expressed at high levels compared to other lipid transport proteins in organs isolated by a blood barrier, such as the brain, the testis and the ovary, suggesting that this molecule plays an important role in lipid homeostasis in localized tissue environments (Burkey et al., 1992).

In the male reproductive tract, a testis specific isoform of apo $J$ is the major secreted protein product of the Sertoli cell (Griswold et al., 1986). Within the lumen of the seminiferous tubules, it binds to sperm plasma membranes, and then dissociates from the spermatozoa within the efferent ducts where it is endocytosed by the nonciliated cells lining the duct (Sylvester et al., 1991). The epididymal apo J isoform - which is differently glycosylated than the testis-specific isoform - is secreted by the epithelial principal cells of the epididymis and vas deferens (Hermo et al., 1991a; Andonian and Hermo, 1999c). The epididymal apo J interacts with the sperm plasma membranes, then dissociates and is taken up by the endocytic apparatus of the principal cells lower down 
the epididymis and vas deferens (Hermo et al., 1991a; Andonian and Hemo, 1999c). It is thought that apo $\mathbb{I}$ is involved in transporting compounds to and from the sperm plasma membrane both in the testis and the epididymis. It has also been suggested that apo $J$ may be providing a protective coating that guards against injurious agents in the luminal fluid. In any case, once its putative function is complete and it dissociates from the sperm plasma membrane, apo J binds to a cell-surface endocytic receptor, megalin, on the nonciliated cells of the efferent ducts and on the principal cells of the epididymis and vas deferens (Igdoura et al., 1994; Morales et al., 1996; Andonian and Hermo, 1999c). Megalin, which will be discussed in the following section, then mediates the endocytosis of apo $J$ through the various endocytic compartments and finally to the lysosomes for degradation (Morales et al., 1996).

\section{Megalin}

\section{Megalin, as a member of the LDL receptor superfamily}

Megalin, also known as low-density lipoprotein receptor-related protein-2 (LRP-2) or gp330, is structurally and functionally related to several other mammalian proteins which, together, make up the low-density lipoprotein receptor family. The other family members include the LDL receptor (LDL-R), the LDL receptor-related protein (LRP), the VLDL receptor (VLDLR), the Apo E receptor 2 (ApoER2) and SORLA-1 (Hussain, 2001). These proteins are all cell-surface receptors involved in receptor-mediated endocytosis. In this process, the receptor extracts and binds ligands from the surrounding extracellular fluid (blood, glomerular ultrafiltrate, etc...) and then interacts with intracellular clathrin to become recruited into a clathrin-coated pit. The clathrin-coated pit subsequently pinches off from the membrane as a clathrin-coated vesicle, which rapidly loses is clathrin coat and transports its contents to endosomes. In endosomes, a

slightly lower $\mathrm{pH}$ allows the ligands to dissociate from the receptors. While the receptors are then recycled back to the cell surface via tubular vesicles, their ligands are then transferred to lysosomes for eventual degradation of the proteinaceous elements and 
cytoplasmic release of the nonprotein fractions (Moestrup and Verroust, 2001; Hussain, 2001). The common functionality of the LDL receptor family members has its foundation in their shared structural elements. Each contains one or more clusters of cysteine-rich complement-type repeats which are the ligand-binding regions of the receptors. Each family member also contains several EGF precursor-type repeats, many of which are separated by spacer regions containing YWTD motifs. These motifs are involved in ligand-receptor dissociation within endosomes (Willnow, 1999). Each member also has a single transmembrane domain and a short cytoplasmic domain containing NPXY motifs which are responsible for binding the clathrin heavy chain and directing the receptors into coated pits (Kibbey et al., 1998).

The ligands of the LDL-R family members include a diverse collection of macromolecules encompassing many lipoproteins, apolipoproteins, proteinases, hormones, vitamins and extracellular matrix proteins (Argraves, 2001). Some ligands, such as apo E, have an affinity for all members of the family, while others are restricted to a particular subset of the members (Hussain, 2001). All LDL-R family members display negative charges while all of their ligands display positive surface charges and it is thought that the high affinity ligand-receptor binding occurs through multiple ionic interactions (Hussain, 2001). The specificity of each receptor for a varying set of ligands may result from the differential clustering of their similar complement-type repeats (Hussain, 2001). All LDL-R members also bind receptor associated protein (RAP) in the rough endoplasmic reticulum (RER). RAP serves as an ER chaperone, preventing the nascent receptors from prematurely binding their ligands in the ER (Birn et al., 2000a). There is also evidence that RAP assists in the proper folding of the receptors ( $\mathrm{Bu}$ and Rennke, 1996).

\section{Structure of megalin}

Megalin is the largest member of the LDL-R family with 4660 amino acids and a glycosylated molecular weight of $600 \mathrm{kDa}$ (Saito et al., 1994). Its large extracellular domain includes 36 cysteine-rich complement-type repeats grouped into four ligand- 
binding domains. These ligand-binding domains are separated by 16 EGF-precursor homology domains containing a total of 40 YWTD repeats, responsible for ligand dissociation. The short intracellular domain (213 aa) contains three consensus clathrinbinding NPXY motifs (Saito et al., 1994).

\section{Distribution and function of megalin}

Megalin is expressed on the apical surface of epithelial cells of several absorptive epithelia including the kidney proximal tubule and glomerulus, ileum, lung, thyroid, thymus, parathyroid, ependyma, eye, inner ear, choroids plexus, oviduct, uterus, epididymis and visceral yolk sac (Hammad et al., 2000; Kounnas et al., 1994; Lundgen et al., 1997; Zheng et al., 1994). Its list of ligands is even more extensive and includes several apolipoproteins, vitamin-carrier complexes, polybasic drugs, enzymes and enzyme inhibitors, hormones and hormone-binding proteins, yielding a total of 36 known ligands to date (Argraves, 2001). The function of megalin is the same in all tissues - that is, the cellular uptake of macromolecules from the surrounding fluid. However, the subset of ligands endocytosed and the greater purpose of this endocytosis are both tissue specific. For example, in the kidney proximal tubule, megalin is responsible for the reabsorption of many ligands from the glomerular ultrafiltrate thus preventing these molecules from being lost in the urine (Christensen and Birn, 2001). Animals with megalin deficiency display low-molecular-weight, tubular proteinuria, highlighting the importance of megalin in retrieving filtered macromolecules (Leheste et al., 1999). Megalin is also essential for fetal development as is dramatically exemplified by the vast majority of megalin knock-out mice. While a few of the knock out animals live to adulthood and simply display the tubular proteinuria phenotype, about $98 \%$ die perinatally of respiratory insufficiency and are disfigured with a severe forebrain malformation called holoprosencephaly (Willnow et al., 1996). The defect involves an incomplete development of the eyes, a lack of olfactory bulbs and corpus callosum, a fused ventricular system and incomplete separation of the forebrain hemispheres (Willnow et al., 1996). Megalin is normally present on the apical aspect of the visceral yolk sac epithelium where it exposed to the yolk sac cavity, rich in maternal nutrients 
(Zheng et al., 1994). It is also expressed on the apical membranes of neuroepithelial cells exposed to the fluid surrounding the embryo at a critical time in forebrain development (Willnow et al., 1996). It has been suggested that megalin is essential for lipoprotein uptake in these embryonic tissues, thereby providing a sufficient supply of cholesterol to the embryo. Cholesterol is essential in the developing animal for extensive membrane synthesis, for cellular growth and to carry out its role as an essential activator for the sonic hedgehog protein (SHH), a key regulator in brain development. Interestingly, both SHH knockout animals and animals with embryonic cholesterol deficiencies display a similar holoprosencephelatic syndrome (Chiang et al., 1996; Tint et al., 1994). Megalin's role in endocytosing its other ligands, including vitamins and minerals, should not be excluded as an essential process in embryogenesis. Maternally-derived vitamin A, another megalin ligand, also accumulates in the visceral sac endoderm and has been implicated in normal brain, cardiovascular, ocular, lung, limb and urogenital development in the embryo (Morriss-Kay and Sokolova, 1996).

\section{Megalin in the male reproductive tract}

Megalin has also been localized to the apical surface of the epithelial cells lining the excurrent duct system of the male. Specifically, it is expressed by the nonciliated cells of the efferent ducts, and the principal cells of the caput, corpus and cauda epididymidis and of the proximal, middle and distal vas deferens (Morales et al., 1996; Andonian and Hermo, 1999c). There is a notable absence of expression in the epithelium of the testis and the initial segment, in the connective tissue and on the spermatozoa. Just as in other absorptive epithelia, epididymal megalin is limited to the apical plasma membrane, coated pits, coated vesicles, endocytic vesicles and early endosomes, but is not found in late endosomes or lysosomes (Morales et al., 1996).

As was previously described, there are a large number of secreted macromolecules in the lumen of the male reproductive tract, many of which may be involved in sperm maturation and many of which are potential megalin ligands. For example, lactoferrin, which has been shown to bind megalin in vitro, is also an epididymal protein (Willnow et 
al., 1992; Jin et al., 1997). Lactoferrin is secreted in all regions of the epididymis from the distal caput to the cauda and has been shown to bind sperm membranes transiently (Jin et al., 1997). However, to date, the only confirmed megalin ligand in the excurrent duct system is the aforementioned apo $J$ molecule. Interestingly, apo $J$ and lactoferrin are among the most abundant epididymal fluid proteins in both the boar and the stallion (Syntin et al., 1996; Fouchecourt et al., 2000). It may soon come to bear that megalin is responsible for the endocytosis of other epididymal molecules. Furthermore, based on the results herein, the role and potential ligands of megalin's co-operative endocytic partner, cubilin (which will be described in the next section), should also be examined in the excurrent duct system.

\section{$\mathbb{E}$. Cubilin}

\section{Structure of cubilin}

Cubilin (also known as gp280) was first identified over 20 years ago as the ileal receptor for intrinsic factor-vitamin $B_{12}\left(\mathbb{F}-B_{12}\right)$, however the primary structure of this large glycoprotein has only recently been elucidated (Seetharam et al., 1981; Moestrup et al., 1998). Cubilin, with 3600 amino acids and significant post-translational glycosylation, has a molecular weight of $460 \mathrm{kDa}$. This endocytic receptor was long known to bind and translocate IF- $\mathrm{B}_{12}$ through the endocytic apparatus of the enterocyte, so it came as a surprise that cubilin has no transmembrane or intracellular domains (Levine et al., 1984; Birn et al., 1997; Moestrup et al., 1998). Instead, cubilin is plasma membrane anchored at its short amino terminus. Cubilin also contains 8 EGF repeats followed by 27 CUB domains, which give cubilin its name (Moestrup et al., 1998). The CUB domain (complement $\mathrm{Clr} / \mathrm{C} 1 \mathrm{~s}$, uegf and bone morphogenic protein 1) is a 110 amino acid module consisting of an antiparallel beta-barrel topology (Bork and Beckmann, 1993). This domain is found in a wide array of functionally diverse proteins including spermadhesins - a family of soluble proteins that assist in sperm-egg interaction and which each consists of a single CUB domain (Bork and Beckmann, 1993). In 
spermadhesins, the CUB domains are known to dimerize in such a way that preferentially exposes the medium beta turns (Varela et al., 1997). If the CUB domains of cubilin follow this same dimerizing arrangement, the least conserved regions would be exposed, thus imparting the molecule with sufficient peptide variation to allow possible interaction with multiple ligands (Kozyraki, 2001).

The 100-amino-acid $\mathrm{NH}_{2}$-terminus contains an amphipathic helix structure with some similarity to the lipid binding regions of apolipoproteins, and this is thought to contribute to the anchoring of the receptor in the cell membrane (Kristiansen et al., 1999). CUB domains 5-8 comprise the binding region for IF- $\mathrm{B}_{12}$ and domains 13-14 are responsible for RAP binding (Kristiansen et al., 1999). However, unlike with megalin, RAP's association with cubilin does not appear to be physiologically significant (Birn et al., 2000a). Cubilin's megalin-binding domain encompasses the $\mathrm{NH}_{2}$-terminus, the eight EGF-like repeats and CUB domains 1-2 (Yammani et al., 2001).

\section{Cubilin's interaction with megalin}

Cubilin has no transmembrane or intracellular domains and is therefore incapable of binding clathrin and mediating its own endocytosis. To become internalized, cubilin is thought to utilize the endocytic machinery of megalin. The evidence for this interaction comes from co-expression studies in both fixed tissues and cell lines; from in vitro binding analyses; and from the inhibition of cubilin ligand internalization using megalin antibodies (Moestrup et al., 1998; Kozyraki et al., 1999; Hammad et al., 2000; Burmeister et al., 2001; Kozyraki et al., 2001; Yammani et al., 2001). As such, the proposed model for their interaction proceeds as follows: cubilin, which is membrane associated, and megalin, with its transmembrane domain, are both on the apical plasma membrane facing the extracellular fluid. Cubilin binds one or several of its ligands and then binds megalin, which may have also bound its own ligands. Megalin then recruits

clathrin with its short intracellular domain and becomes localized within a clathrin-coated pit. The two receptors, along with their respective ligands, travel together through the endocytic apparatus until they reach the late endosomes (or multivesicular bodies). 
There, due to the low acidity of this compartment, the receptors and their ligands segregate. The ligands proceed to the lysosomes for further processing while the receptors are recycled back to the plasma membrane. Whether cubilin and megalin remain bound through the entire endocytic apparatus remains to be determined, though the finding that the binding of the two receptors remains unaltered between $\mathrm{pH} 4-8$ suggests that they remain attached in these compartments (Moestrup et al., 1998).

\section{Distribution of cubilin}

To date, the known tissue distribution of cubilin is more restricted than that of megalin. Cubilin has been localized to the ileal epithelium, renal proximal tubule, visceral yolk sac, thymus, placenta, lung, oviduct and uterus (Seetharam et al., 1981; Sahali et al., 1992; Hammad et al., 2000; Moestrup and Verroust, 2001). In every tissue examined at a subcellular level, cubilin and megalin co-localize to the apical plasma membrane and endocytic apparatus, and both are rarely found in the lysosomes. Although many tissues remain to be studied, so far, the rat glomerulus is the only tissue in which megalin is found without the co-expression of cubilin (Zheng et al., 1994; Seetharam et al., 1988).

\section{Cubilin's ligands}

As was previously mentioned, cubilin was first identified as the receptor for IF-B $B_{12}$ in the ileum (Seetharam et al., 1981). The recent cloning of cubilin was initiated when it was extracted from renal cortex membranes by affinity chromatography onto a RAPSepharose column (Birn et al., 1997). Again, the physiological significance of the cubilin:RAP interaction remains unknown. Shortly after its cloning, cubilin was found to be the receptor of Ig light chains and Apo A-I in both the yolk sac and the kidney (Batuman et al., 1998; Hammad et al., 1999; Kozyraki et al., 1999). Albumin, which is a megalin ligand, was also shown to be taken up by cubilin in the renal proximal tubule (Bim et al., 2000b). In the past year, five new cubilin ligands have been discovered, suggesting that, like megalin, cubilin may also serve as a scavenger receptor in the kidney 
and yolk sac. These newly unearthed ligands include transferrin, clara cell secretory protein (CCSP), 25(OH) vitamin $\mathrm{D}_{3}$, hemoglobin and galectin-3 (Kozyraki et al., 2001; Burmeister et al., 2001; Nykjaer et al., 2001; Gburek et al., 2002; Crider-Pirkle et al., 2002). These cubilin ligands, much like the previously mentioned megalin ligands are vitamin-binding, lipid-binding and mineral-binding proteins all of which imply a significant nutritional functionality of these receptors.

\section{Physiological roles of cubilin}

The physiological importance of the ileal absorption of vitamin $\mathrm{B}_{12}$ is highlighted by a human condition called Imerslund-Gräsbecks disease. This disease is characterized by a defective intestinal malabsorption of vitamin $B_{12}$ but is also sometimes accompanied by tubular proteinuria (Broch et al., 1984; Gräsbeck et al., 1960). Two mutations in the cubilin gene have been associated with this disease. The most prevalent, FM1, is a point mutation in the CUB 8 domain which affects the binding of cubilin to IF-B $B_{12}$ and which is only associated with a mild proteinuria (Aminoff et al., 1999, Kristiansen et al., 2000). A more severe mutation, FM2, which results in cryptic intronic splice in CUB 6 and a truncated protein, is accompanied by a severe proteinuria (Aminoff et al., 1999). Treatment with vitamin $B_{12}$ cures all symptoms except the proteinuria, suggesting that this particular symptom does not result from a lack of $B_{12}$, but rather can be attributed to the defective cubilin function in the proximal convoluted tubule of the kidney.

Indeed, the urine of FM2 patients has been shown to specifically contain large amounts of apo A-I, 25(OH) vitamin $\mathrm{D}_{3}$, transferrin and CCSP (Kozyraki et al., 1999; Nykjaer et al., 2001; Kozyraki et al., 2001; Burmeister et al., 2001). Furthermore, dogs lacking functional cubilin also excrete large amounts of albumin, apo A-I, $25(\mathrm{OH})$ vitamin $\mathrm{D}_{3}$ and transferrin in their urine (Birn et al., 2000b; Kozyraki et al., 1999; Nykjaer et al., 2001; Kozyraki et al., 2001). In the normal kidney, proteins are filtered through the glomerulus into bowman's capsule, then internalized and degraded in the epithelial cells of the proximal convoluted tubule. Very little protein is ever lost in the 
urine. However, in those animals with a defective cubilin structure or expression, this process of protein reabsorption is compromised.

Although cubilin's role in the kidney may be simply to prevent the loss of proteins and protein-bound nutrients into the urine, in the yolk sac, by executing the same receptormediated endocytosis, cubilin is functioning to deliver amino acids and essential nutrients to the developing embryo. In the rat, cubilin is expressed at day 7 in the endodermal cells that give rise to the epithelial cells of the visceral yolk sac. The yolk sac completely surrounds the embryo throughout gestation and is the sole tissue interface between the mother and fetus during the critical phase of organogenesis (Lloyd, 1990). Anti-cubilin antibodies introduced into the developing embryo cause severe fetal malformations (Sahali et al., 1988). Although the direct causal link between the cubilin antibodies and the malformations has yet to be determined, it is thought that cubilin's role in internalizing maternal proteins, vitamins, minerals and perhaps most importantly, lipoproteins is essential in this respect. It is thought that cubilin's uptake of maternal proteins, with subsequent catabolism in the lysosomes provides a large supply of amino acids to the developing embryo. More importantly however, since many studies have linked a decreased cholesterol availability in the embryo with the induction of fetal malformations, cubilin as the apo A-I and HDL receptor is thought to be critical for the developing animal (Roux et al., 2000).

The research herein takes the initial steps to examine, for the first time, the distribution of cubilin in the excurrent ducts of the male reproductive tract. Its coexpression and interaction with its endocytic partner, megalin, are also examined in this in vivo system. 


\section{MATERIALS AND METHODS}

\section{A. Antilibodics and reagents}

Recombinant human RAP was purified as described (Williams et al., 1992). Rabbit polyclonal antiserum to a bacterially expressed amino-terminal segment of rat cubilin has been described previously (Hammad et al., 2000). Rabbit polyclonal antiserum to porcine megalin has also been described (Hammad et al., 1997). Goat anti-rabbit IgG conjugated to horseradish peroxidase (HRP) and colloidal gold-conjugated goat anti-rabbit IgG were purchased from Cedarlane (Homby, ON). Unless otherwise indicated, all other reagents were obtained from Sigma Chemical Co. (St. Louis, MO).

\section{P. RNA isolation and RT-PCR}

Adult male Sprague-Dawley rats (350-400 grams) were obtained from Charles River Laboratories (St.Constant, QC). Animals were anaesthetized with an intraperitoneal injection of sodium pentobarbital $(100 \mu 1 / 100 \mathrm{~g}$ tissue; MTC Pharmaceuticals, Hamilton, ON). Anaesthetized animals were perfused with Ringer's saline through the heart. The reproductive tract and kidney cortex and were removed, sectioned and immediately frozen in liquid nitrogen. For RNA isolation $-20 \mathrm{mg}$ of frozen tissue was extracted with reagents supplied in a kit (RNeasy, Qiagen, Mississauga, ON) using a Tekmar tissumizer at half speed for $1 \mathrm{~min}$. RNAse-free DNAse I was added during the RNA isolation procedure to digest DNA contamination. Total RNA $(0.8 \mu \mathrm{g})$ was used as template for reverse transcription using random hexamer primers (Promega, Madison, WI), dNTPS (Gibco, Grand Island, NY), RNasin (Promega) and Omniscript reverse transcriptase (Qiagen) according to manufacturer instructions. The cDNA product was used as template with specific oligonucleotide primers, dNTPS, Taq polymerase (Qiagen) and a thermal cycling profile of $55^{\circ} \mathrm{C}$ for $1 \mathrm{~min}, 72^{\circ} \mathrm{C}$ for $1 \mathrm{~min}$ and $94^{\circ} \mathrm{C}$ for $1 \mathrm{~min}$, that was repeated 35 times. We designed three sets of specific primers for the PCR: cubilin sense 
5'GAGACGGAGGCTACGAAACG3' (residues 3329-3348) and antisense

5'TAGTCGGGCCATCAAACACG3' (residues 3691-3672) primers were designed from the rat cubilin mRNA (accession number AF022247); megalin sense 5'GGTGTGTGACGAGGATAAGG3' (residues 377-396) and antisense 5'AGTTGCAATTGCGCTCATCG3' (residues 777-758) primers were designed from the rat megalin mRNA (accession number NM_030827); and positive control $\beta$-actin sense 5'CTCTCTTCCAGCCTTCCTTC3' (residues 2573-2592) and antisense 5'AGAGCCACCAATCCACACAG3' (residues 3038-3019) primers were designed from the rat $\beta$-actin gene (accession number V01217 J00691). Control reactions for each primer pair were also performed in the absence of reverse transcriptase or cDNA template.

\section{Immunoblot analysis}

Frozen tissues (kidney and the various segments of the reproductive tract) were extracted on ice in homogenization buffer ( $5 \mathrm{mM}$ Tris, $0.25 \mathrm{M}$ sucrose, $1 \mathrm{mM}$ phenylmethylsulfonyl fluoride (PMSF), $10 \mu \mathrm{g} / \mathrm{ml}$ leupeptin, $10 \mu \mathrm{g} / \mathrm{ml}$ aprotinin, $\mathrm{pH}$ 7.6) using a Tekmar tissumizer at half speed for $1 \mathrm{~min}$. Homogenates were subjected to centrifugation at $12,000 \mathrm{x}$ f for $10 \mathrm{~min}$ and supernatants were then centrifuged at 100,000 $\mathrm{x} \mathrm{g}$ for $1 \mathrm{hr}$. Pellets were dissolved in homogenization buffer and protein concentration was determined using a Bradford-type assay (BioRad, Hercules, CA). Aliquots containing 50 $\mathrm{gg}$ of protein were run under non-reducing conditions on $5 \%$ polyacrylamide gels and the separated proteins transferred to nitrocellulose membranes. Unoccupied sites on the membrane were blocked in blocking buffer (5\% BSA, 5\% nonfat dried milk, $0.1 \%$ Tween in TBS, pH 7.4). Membranes were incubated with cubilin antibody $(3.2 \mu \mathrm{g} / \mathrm{ml})$ in blocking buffer containing $0.1 \%$ Tween. Bound antibodies were detected using HRP-conjugated anti-IgG and ECL Plus Detection Kit (Amersham Pharmacia, Baie D'Urfe, QC). 


\section{Immanohistochemical staining}

The reproductive tract was fixed by a 10 min perfusion with Bouin's fixative via the abdominal aorta of anaesthetized rats. Following perfusion, efferent ducts, epididymis and vas deferens were removed and immersed in Bouin's fixative for an additional $24 \mathrm{hr}$. The tissues were then dehydrated in graded ethanol and embedded in paraffin. Sections $5 \mu \mathrm{m}$ thick were cut and mounted on glass slides. Sections were then de-paraffinized with Histo-Clear and rehydrated in a series of ethanol solutions $(100 \%, 95 \%, 70 \%, 70 \%, 70 \%$, $70 \%, 50 \%)$. Hydrogen peroxide ( $1 \% \mathrm{v} / \mathrm{v})$ was added to the second $70 \%$ ethanol bath. Lithium carbonate $(1 \% \mathrm{w} / \mathrm{v})$ was added to the third $70 \%$ ethanol bath to neutralize residual picric acid from the Bouin's fixative. The slides were then placed in a $300 \mathrm{mM}$ glycine bath for 5 min to block free aldehyde groups. To uncover antigenic sites on the tissues, the slides were immersed in an antigen retrieval solution $(1.8 \mathrm{mM}$ citric acid, $8.2 \mathrm{mM}$ sodium citrate, $\mathrm{pH}$ ) and heated to boiling in a microwave oven several times. After cooling, the slides were blocked with $10 \%$ goat serum in TBS (20mM Tris, $150 \mathrm{mM}$ $\mathrm{NaCl}, 0.1 \% \mathrm{BSA}, \mathrm{pH} 7.4$ ) and incubated for $15 \mathrm{~min}$ at $37^{\circ} \mathrm{C}$. Slides were washed in TBSTween $(0.1 \%$ Tween in TBS) before incubating for $90 \mathrm{~min}$ with cubilin antibody $(128 \mu \mathrm{g} / \mathrm{ml})$. This was followed by an incubation with $10 \%$ goat serum for $15 \mathrm{~min}$ and several washes with TBS-Tween. Goat anti-rabbit IgG $(7.5 \mu \mathrm{g} / \mathrm{ml})$ conjugated to HRP was applied to the sections and incubated for $30 \mathrm{~min}$. Slides were again washed in TBSTween and immersed for $10 \mathrm{~min}$ in DAB solution (TBS with $0.05 \%$ diaminobenzidine tetrahydrochloride, $0.1 \mathrm{M}$ imidazole, $0.03 \%$ hydrogen peroxide, $\mathrm{pH} 7.6$ ). Following rinsing with distilled water and counterstaining with methylene blue, the sections were rehydrated in a series of ethanol solutions and Histo-clear. Coverslips were mounted using Permount. 


\section{E. Immunogold electron-microscopy}

The male reproductive tract was fixed with $4 \%$ paraformaldehyde, $0.25 \%$ glutaraldehyde $-15 \mathrm{mM}$ lysine in $0.1 \mathrm{M}$ phosphate buffer, $\mathrm{pH} 7.5$ by perfusion through the abdominal aorta of anaesthetized rats. Tissues were removed, sectioned, left in the same fixative for $2 \mathrm{hr}$ and then washed in $\mathrm{PBS}\left(137 \mathrm{mM} \mathrm{NaCl}, 2.7 \mathrm{mM} \mathrm{KCl}, 1.5 \mathrm{mM} \mathrm{KH} \mathrm{PO}_{4}\right.$, $6.5 \mathrm{mM} \mathrm{Na}_{2} \mathrm{HPO}_{4}, \mathrm{pH} 7.4$ ). Tissue blocks were dehydrated in graded ethanol, embedded in Lowicryl K11M (Polysciences, Warrington, PA), and cut into ultrathin sections, which were mounted on 200 -mesh formvar-coated nickel grids. After a $15 \mathrm{~min}$ incubation with $10 \%$ goat serum in TBS the grids were incubated in cubilin antibody $(320 \mu \mathrm{g} / \mathrm{ml})$ for 90 min, followed by TBS-Tween washings. The grids were incubated in 10\% goat serumTBS then with goat anti-rabbit $\operatorname{IgG}(0.41 \mu \mathrm{g} / \mathrm{ml})$ conjugated to $10 \mathrm{~nm}$ gold particles followed by several TBS-Tween washes. For double antibody labeling the entire labeling process was repeated using megalin antibodies $(265 \mu \mathrm{g} / \mathrm{ml})$ as the primary antibody and goat anti-rabbit conjugated to $15 \mathrm{~nm}$ gold particles as the secondary antibody. Grids were blotted dry and counterstained by incubating each grid in $4 \%$ uranyl acetate for 2 min and $3 \%$ lead citrate for $30 \mathrm{sec}$.

\section{T. Injection of efrerent ducts and vas deferens}

RAP ( $200 \mu \mathrm{l}$ of $0.2 \mathrm{mg} / \mathrm{ml}$ in PBS containing $0.01 \%$ trypan blue) was injected into the left efferent ducts of three animals through the rete testes as described by Morales and Hermo (1983). The right efferent ducts of these animals were injected with $200 \mu l$ of

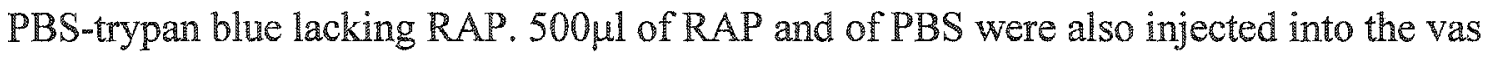
deferens of a different set of animals. Thirty minutes post injection the tissues were fixed, embedded and immunolabeled as described above. 


\section{RESULTS}

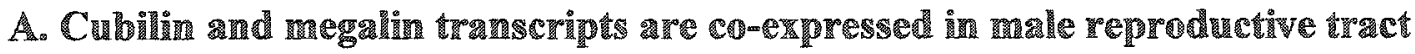 tissues}

Cubilin and megalin have recently been co-localized in various polarized epithelia and, by immunocytochemistry, megalin has been found in the male reproductive system (Moestrup and Verroust, 2001; Morales et al., 1996). Here we used RT-PCR to determine the localization of cubilin and megalin mRNA transcript in the efferent ducts, epididymis and vas deferens. Specific primers were used to amplify a $363 \mathrm{bp}$ fragment of cubilin cDNA. RT-PCR on efferent ducts, corpus and cauda epididymidis and proximal and distal vas deferens all resulted in $360 \mathrm{bp}$ amplicons (Fig. 1A). Caput epididymidis (Fig. $1 \mathrm{~A}$, lane 4) was the only tissue that did not yield an amplified fragment. Kidney, which was used in this and in subsequent experiments as a positive control for cubilin - because this protein is known to be expressed in the proximal convoluted tubules - also yielded a $360 \mathrm{bp}$ amplicon (Fig. 1A, lane 2).

To control for presence of mRNA, $\beta$-actin was used as a positive control (Fig. 1B). Since cubilin does not have any reported introns, $\beta$-actin specific primers were also selected to span an intron and thus control for DNA contamination. The $\beta$-actin primers would amplify a $465 \mathrm{bp}$ fragment of DNA but only a $253 \mathrm{bp}$ fragment of cDNA. As there are no 465 bp bands, there was no DNA contamination (Fig. 1B). Furthermore, negative controls for the reverse transcription (devoid of reverse transcriptase) and for the PCR (devoid of cDNA) yielded no amplicons (not shown).

The same RT-PCR was conducted using specific primers for megalin. Primers used to amplify a $401 \mathrm{bp}$ fragment of megalin cDNA resulted in positive bands on all tissues examined (Fig. 2A). $\beta$-actin controls (Fig. 2B) yielded expected bands and negative controls yielded no amplicons (not shown). 


\section{B. Immunoblot and immunocytochemical analysis of cubilin expression in male reproductive tract tissues}

In order to correlate our mRNA localization with its translation product, we used two different techniques: immunoblot analysis and light microscope immunocytochemistry. Immunoblot analysis of microsomal extracts of the efferent ducts, corpus and cauda epididymidis and proximal and distal vas deferens showed that each tissue expressed a cubilin antibody-reactive polypeptide having a relative molecular mass of $460 \mathrm{kDa}$ (Fig. 3). The 460-kDa polypeptide was not detected in extracts of caput epididymidis (Fig. 3, lane 3), but was detected in extracts of kidney (Fig. 3, lane 1), as previously reported (Seetharam et al., 1988).

Immunohistochemical analysis of tissues of the male reproductive tract provided further localization detail and allowed us to determine the cell types expressing this protein. In the testis, no cubilin expression was detected either in the seminiferous epithelium or in the Leydig cells (Fig. 4A). In the efferent ducts, cubilin was expressed in the apical region and within apical vesicles of nonciliated cells (Fig. 4C). By contrast, ciliated cells showed no detectable cubilin expression. No cubilin expression was detected in the initial segment (Fig. 5A) or in the caput epididymidis (Fig. 5C). In the corpus and cauda epididymidis (Fig. 6A and 6C) diffuse cubilin staining was detected within the apical cytoplasm of principal cells that progressively intensified down the epididymis. Some principal cells displayed no detectable cubilin expression, thus yielding a "checkerboard" staining pattern of the principal cells. Basal cells and clear cells also displayed no cubilin expression. In the proximal and middle vas deferens, principal cells displayed a punctate apical staining pattern (Fig. 7A and 7C) whereas clear and basal cells again displayed no cubilin expression. Again, a "checkerboard" staining pattern of the principal cells was observed in these regions. No cubilin expression was detected in any connective tissue elements or on spermatozoa anywhere along the tract. A positive control for antibody specificity showed the cubilin antibody detected cubilin in the brush border of renal proximal convoluted tubule cells but showed no reactivity with cells of the distal convoluted tubules or glomeruli (Fig. 8A) in accordance with previously 
published findings (Seetharam et al., 1988). The pattern of expression of megalin in the male reproductive system has been previously described (Morales et al., 1996; Andonian and Hermo, 1999c). Table 1 compares the pattern of cubilin expression observed in the present study with that of megalin in tissues of the male reproductive tract.

\section{Cubilin traffies with megalin in endocytic compartments}

Immunogold electron microscopy (immunogold EM) was used to characterize the subcellular localization of cubilin in male reproductive tract epithelia. Cubilin was found in apical endocytic compartments of epithelial cells of the efferent ducts, the corpus and cauda epididymidis, and the proximal and distal vas deferens. Specifically, it was detected at the base of microvilli, in endocytic pits and vesicles and in endosomes of these cells (Fig. 9). Late endosomes (or multivesicular bodies) showed few cubilin gold particles and lysosomes were devoid of gold particles (Fig. 10). Double immunogold EM was performed to examine the subcellular distribution of cubilin and megalin. Cubilin (marked by $10 \mathrm{~nm}$ gold particles) and megalin ( $15 \mathrm{~nm}$ gold particles) were found to colocalize in the same endocytic compartments again with few gold particles in the late endosomes and an absence of gold particles in the lysosomes (Fig. 11A and B). There were also vesicles containing cubilin and megalin seemingly budding off of late endosomes or multivesicular bodies (Fig. 12A and B).

\section{RAP, the antagonist of megalin:cubilin interaction, inhibits cubilin uptake}

Previous studies have demonstrated an in vitro binding between cubilin and megalin and here we have demonstrated the co-localization of cubilin and megalin in the endocytic apparatus of the epithelium of the excurrent duct system (Moestrup et al., 1998). To evaluate the possibility that megalin might be responsible for the uptake and subcellular trafficking of cubilin we injected $\mathrm{RAP}$, an antagonist of the megalin:cubilin interaction, into the lumen of the efferent ducts and vas deferens (Moestrup et al., 1998). 
A PBS injection served as a comparative control. Immunogold EM analysis of the RAPand PBS-injected tissues revealed that RAP treatment reduced the amounts of cubilin in endocytic compartments compared to the PBS control in both the efferent ducts (Fig. 13) and the vas deferens (Fig. 14). Quantitative analysis of the immunogold labeling data using one-way ANOVA indicated that the RAP treatment produced nearly a three-fold reduction of cubilin in the efferent ducts and nearly a four-fold reduction in vas deferens as compared to controls (Fig. 15). 
FIGURES AND TABLES 
Figure 1. RT-PCR analysis of cubilin mRNA expression in various tissues of the male reproductive tract. Shown are RT-PCR amplicons obtained using primers specific for cubilin (A) and $\beta$-actin (B) with cDNA templates prepared from total RNA isolated from rat kidney (lane 2), efferent ducts (lane 3), caput (lane 4), corpus (lane 5) and cauda epididymidis (lane 6), proximal vas deferens (lane 7) and distal vas deferens (lane 8). $100 \mathrm{bp}$ ladder in lane 1. 


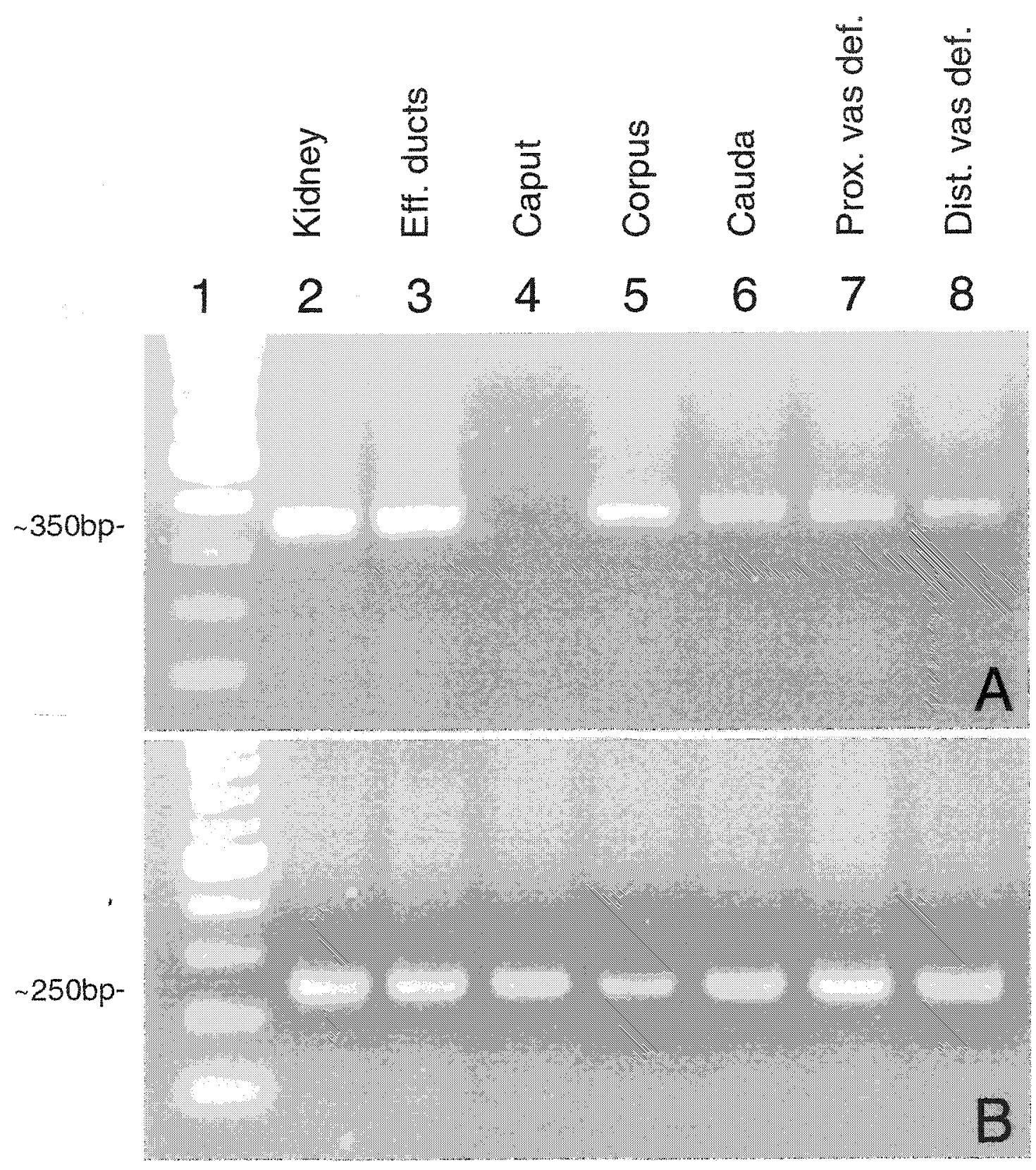


Figure 2. RT-PCR analysis of megalin mRNA expression in various tissues of the male reproductive tract. Shown are RT-PCR amplicons obtained using primers specific for megalin (A) and $\beta$-actin (B) with cDNA templates prepared from total RNA isolated from rat kidney (lane 2), efferent ducts (lane 3), caput (lane 4), corpus (lane 5) and cauda epididymidis (lane 6), proximal vas deferens (lane 7) and distal vas deferens (lane 8). $100 \mathrm{bp} \mathrm{ladder} \mathrm{in} \mathrm{lane} 1$. 


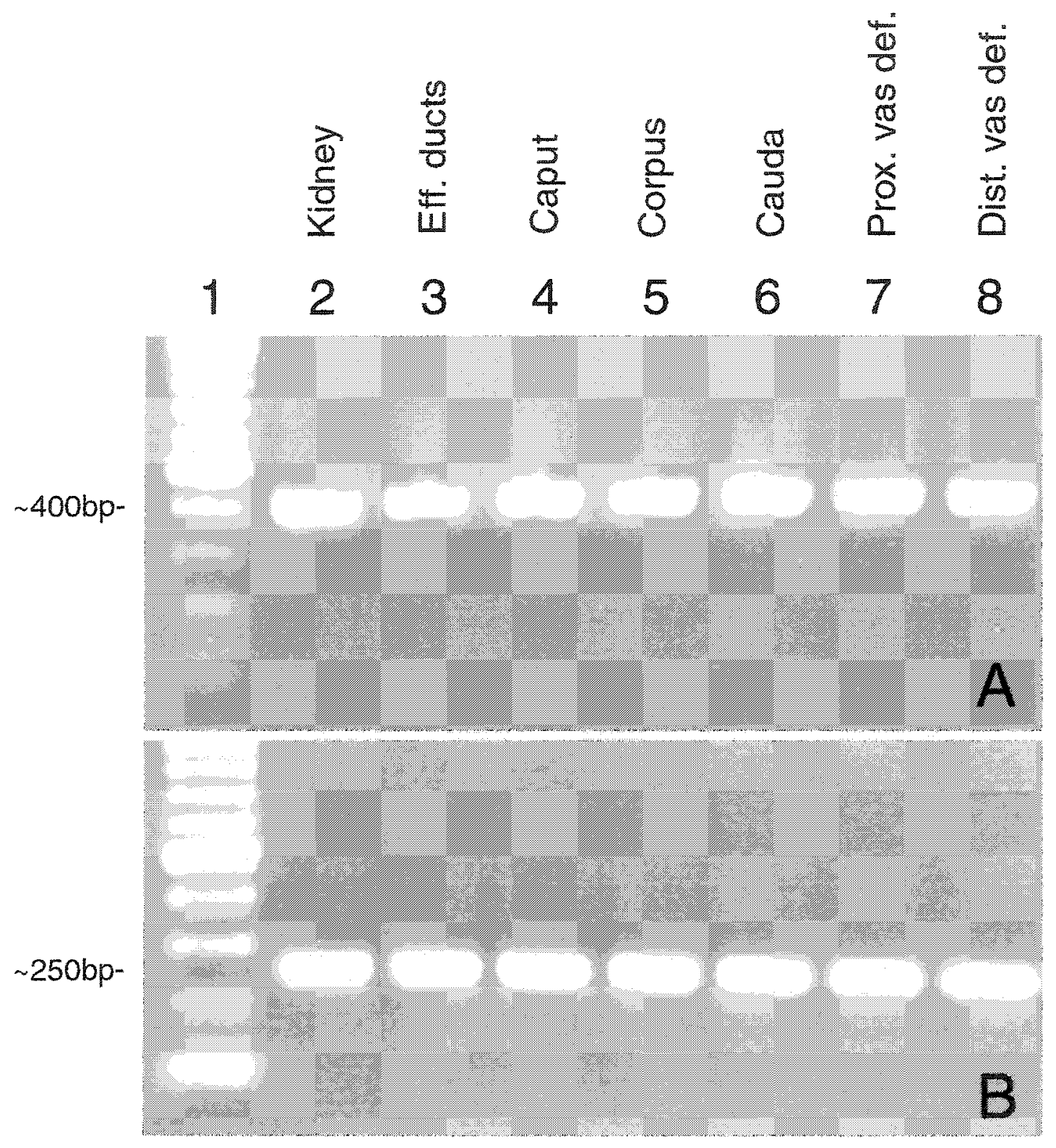


Figure 3. Tmmunoblot amalysis of cubilin expression in reproductive tissue extracts. Aliquots from microsomal fractions isolated from kidney (lane 1), efferent ducts (lane 2), caput (lane 3), corpus (lane 4) and cauda epididymidis (lane 5), proximal vas deferens (lane 6) and distal vas deferens (lane 7) were electrophoresed under non-reducing conditions on $5 \%$ polyacrylamide gels and transferred to nitrocellulose membranes. The membranes were stained using rabbit antibodies to cubilin and counter stained with HRP. conjugated anti-IgG. 


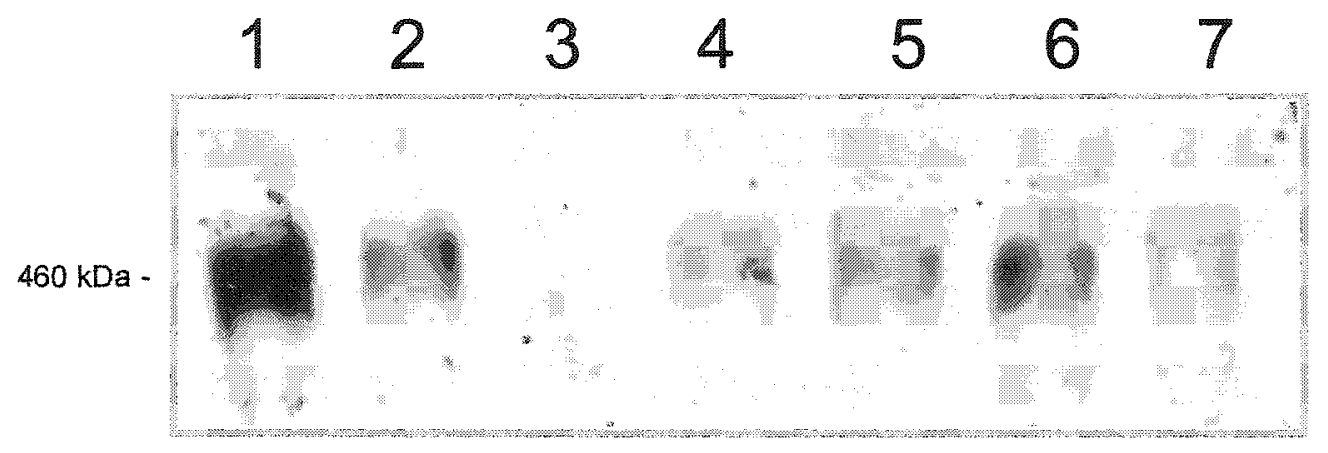


Figure 4. Immunolocalization of cubilin in the testis and efferent ducts.

Shown are micrographs of anti-cubilin immunocytochemical staining of sections from rat testis (A) and efferent ducts (C). In the testis, neither the seminiferous epithelium nor the interstitial space display cubilin staining. In the efferent ducts, strong cubilin staining is observed in the apical vesicles of the ciliated cells of the efferent ducts (arrowheads) whereas nonciliated cells show little or no staining (not shown). Connective tissue elements and spermatozoa in both regions show no detectable cubilin staining. Negative controls $(B, D)$ for each tissue are shown to the right of each image and neither displays HRP staining.

L: Iumen; A, B x322; C,D x1100 

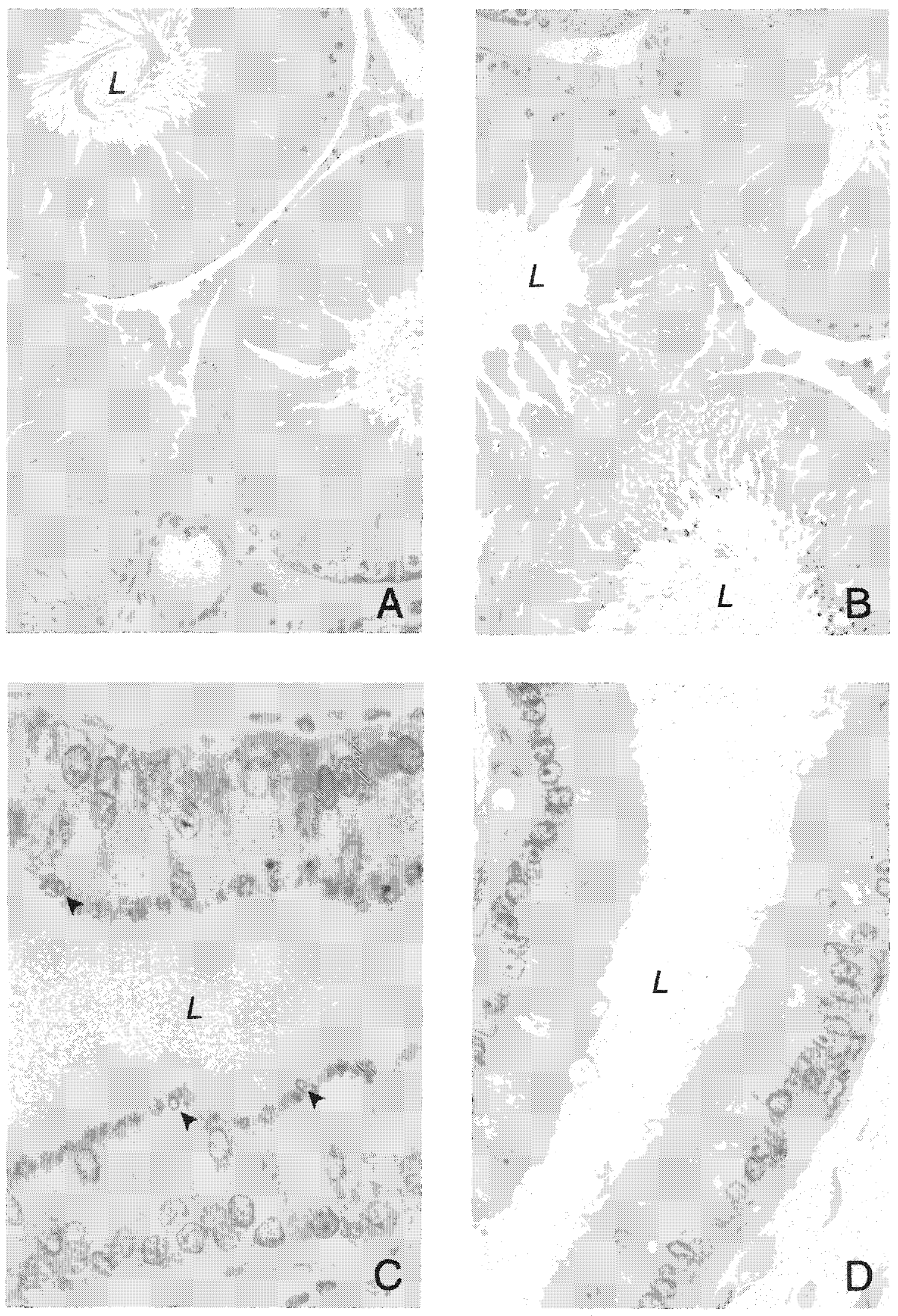


\section{Figure 5. Immunolocalization of cubilim in the initial segment and caput}

epididymidis. Shown are micrographs of anti-cubilin immunocytochemical staining of sections from the rat initial segment (A) and caput epididymidis (C). In both the initial segment and the caput epididymidis, none of the epithelial cells display cubilin staining. Connective tissue elements and spermatozoa in both regions are also void of cubilin staining. Negative controls $(B, D)$ for each section are shown to the right of each image and neither displays HRP staining.

L: lumen; $A, B \times 400 ; C, D \times 470$ 


Figure 6. Immumolocalization of cubilin in the corpus and cauda epididymidis.

Shown are micrographs of anti-cubilin immunocytochemical staining of sections from the rat corpus epididymidis (A) and cauda epididymidis (C). In both the corpus and the cauda, most principal cells show a strong but diffuse apical staining for cubilin (arrowheads). A smaller number of principal cells show no cubilin staining (arrows), thus creating a checkerboard pattern of principal cells. Clear cells show no detectable cubilin staining (asterisks). Connective tissue elements and spermatozoa in both regions also show no detectable cubilin staining. Negative controls $(\mathrm{B}, \mathrm{D})$ for each section are shown to the right of each image and neither displays HRP staining.

L: lumen; A, B x450; C, D x600 

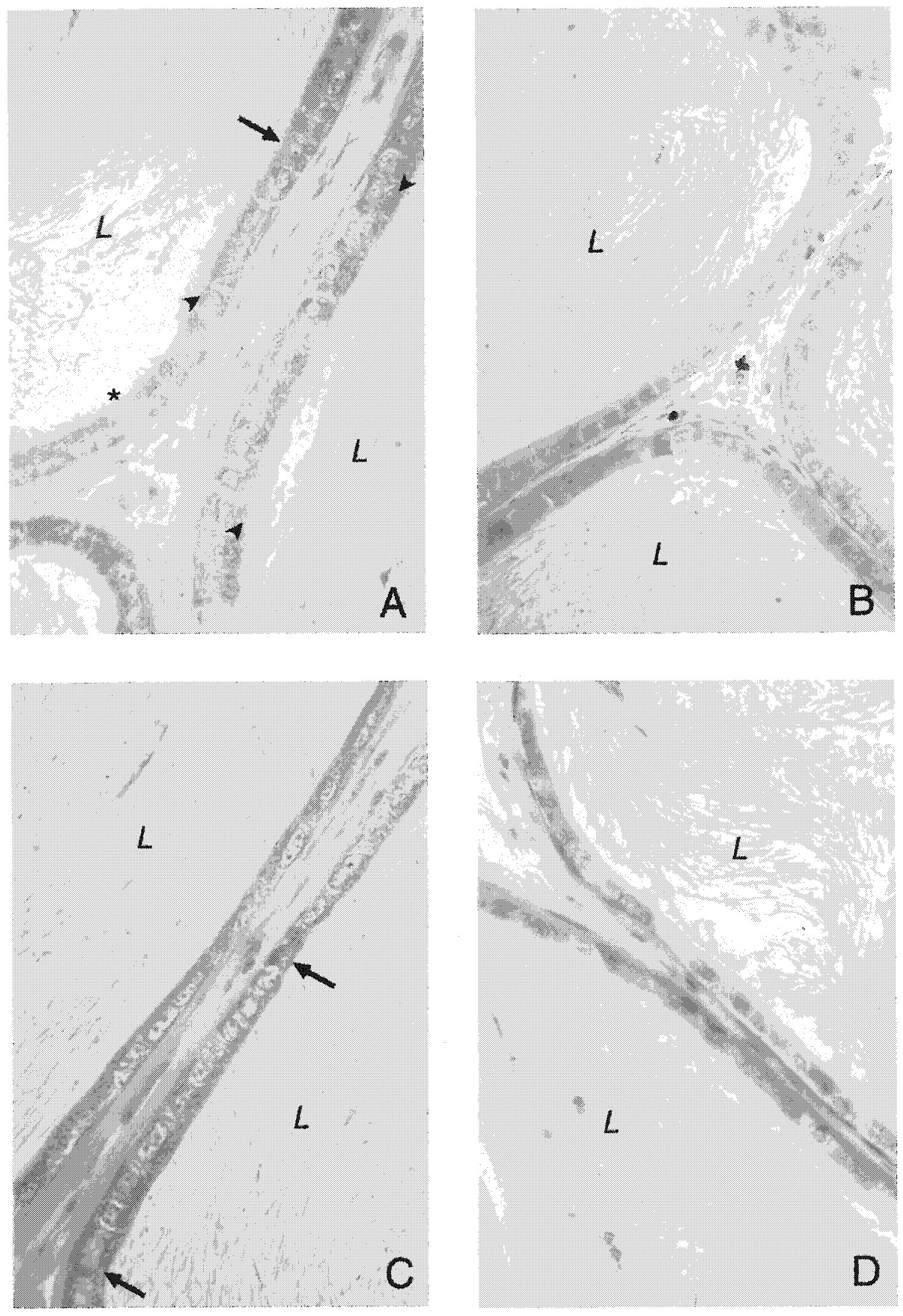
Figure 7. Immunolocalization of cubilin in the proximal and middle vas deferens. Shown are micrographs of anti-cubilin immunocytochemical staining of sections from rat proximal vas deferens $(A)$ and middle vas deferens $(C)$. In the principal cells of the proximal vas deferens, pronounced cubilin staining is observed in the apical cytoplasm and is dotted with strong vesicular staining (arrowheads). In the middle vas deferens, punctate cubilin staining is observed in the apical vesicles of the principal cells (arrowheads). Some principal cells do not stain (arrows) again yielding a checkerboard staining pattern in these regions. Connective tissue elements and spermatozoa in both regions show no detectable cubilin staining. Negative controls (B,D) for each section are shown to the right of each image and neither displays HRP staining. L: lumen; A, B x1970; C,D x2250 

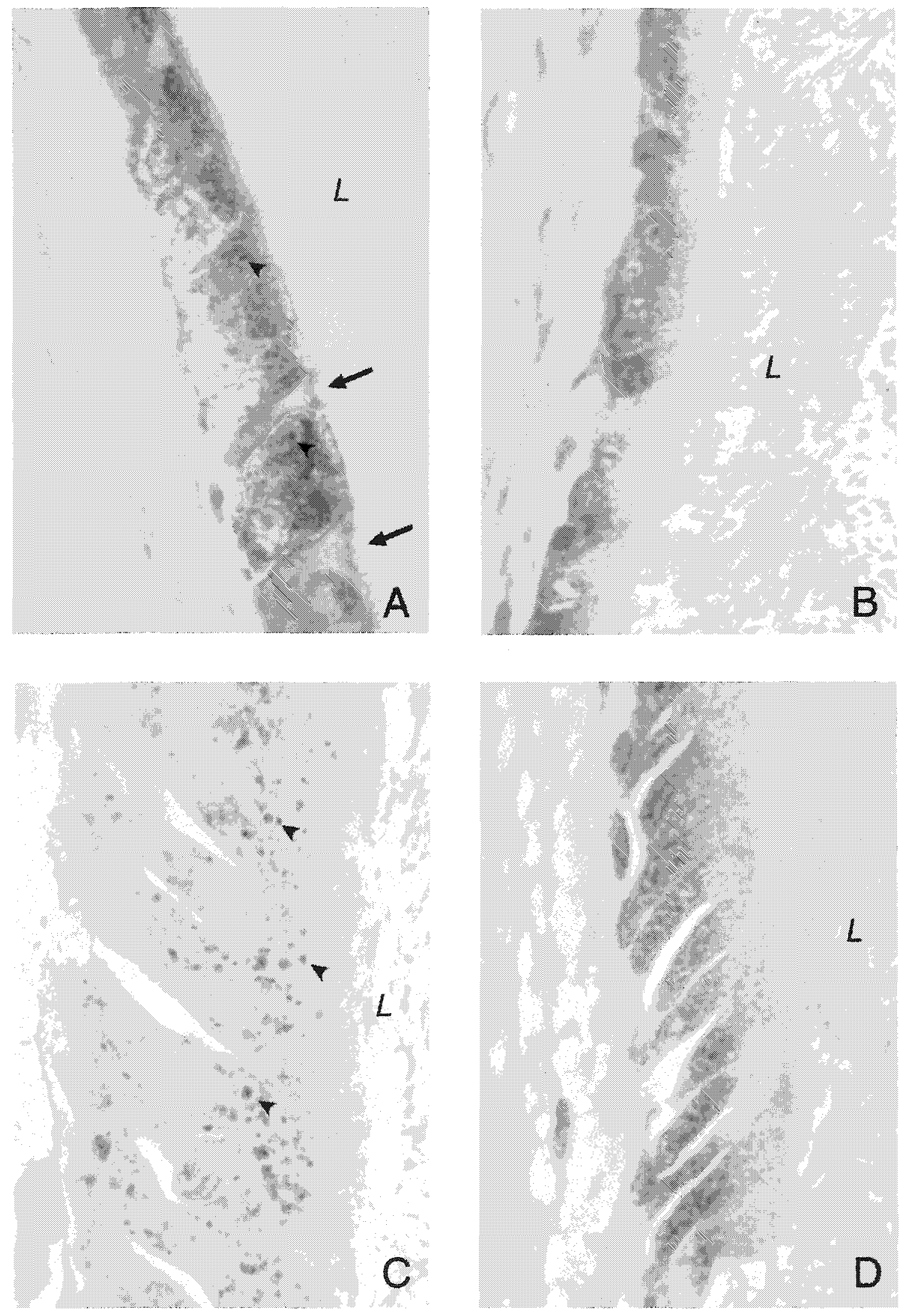


\section{Figure 8. Immunolocalization of cubilin in the kidney.}

Shown are micrographs of anti-cubilin immunocytochemical staining of sections from rat kidney (A). Pronounced cubilin staining is observed in the brush boarder and apical aspect of the proximal convoluted tubules of the kidney (arrowheads). Distal convoluted tubules and glomeruli are devoid of staining. Connective tissue elements also show no detectable cubilin staining. A negative control (B) is shown to the right of the image and does not display HRP staining.

d: distal convoluted tubule; p: proximal convoluted tubule; g: glomerulus; A, B x880 

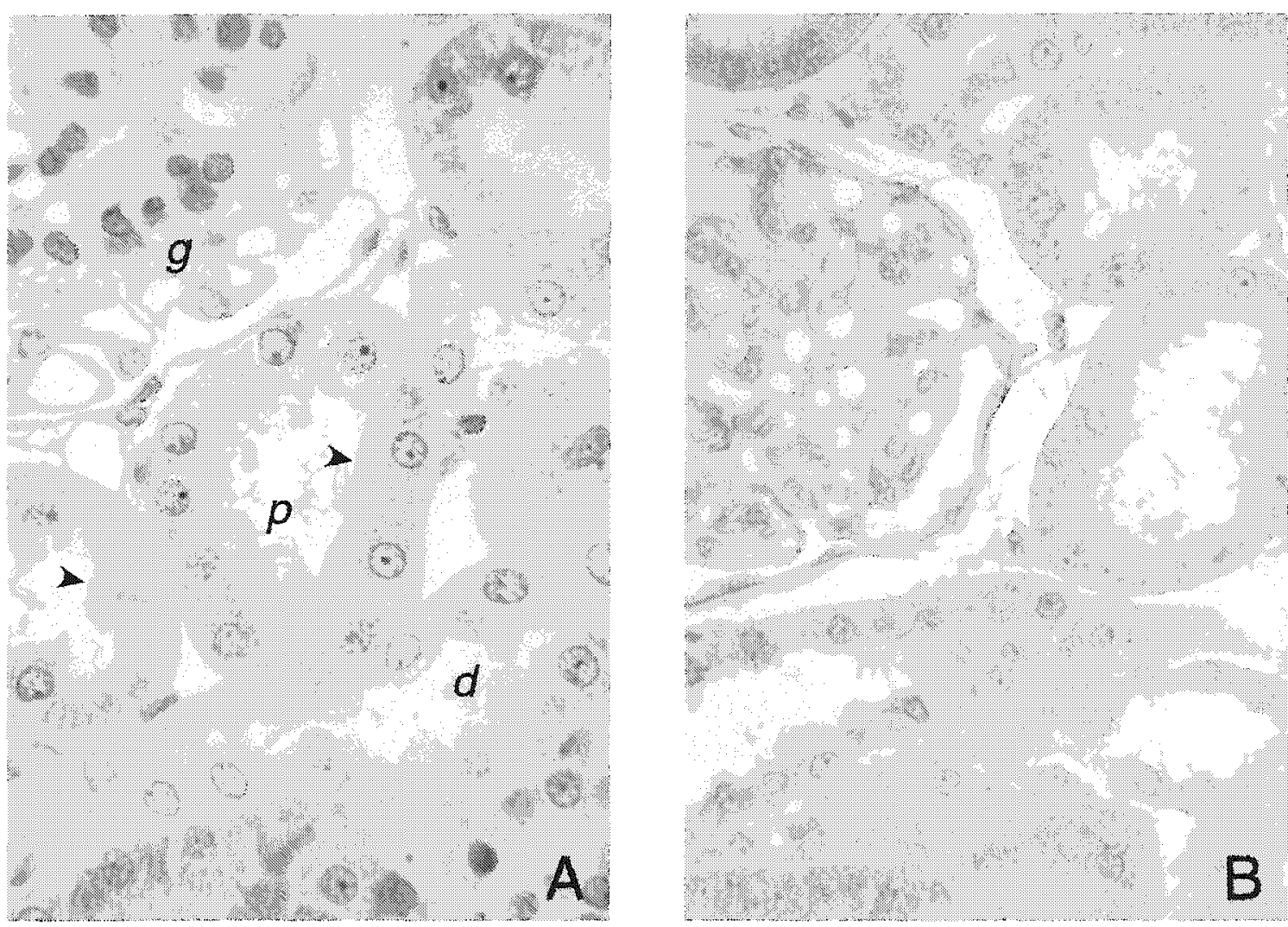
Table 1. Immunolocalization of cubilin and megalin in the male reproductive tract. 


\section{Table 1}

Immunolocalization of cubilin and megalin in various regions of the male reproductive tract.

\begin{tabular}{|l|c|c|}
\hline Region & Cubilin & Megalin \\
\hline Testis & - & $=$ \\
\hline Efferent Ducts & ++ & +++ \\
\hline Initial Segment & $=$ & $=$ \\
\hline Proximal Caput & - & +++ \\
\hline Distal Caput & - & $+/$ \\
\hline Corpus & $++(\mathrm{CB})$ & +++ \\
\hline Cauda & $+++(\mathrm{CB})$ & +++ \\
\hline Proximal Vas Deferens & $++(\mathrm{CB})$ & ++ \\
\hline Middle and Distal Vas Deferens & $++(\mathrm{CB})$ & ++ \\
\hline
\end{tabular}

'From Morales et al. 1996 and Andonian and Hermo 1999; +, indicates relative intensity of staining; -, indicates lack of staining; $C B$, indicates a checkerboard staining pattern. 
Figure 9. Electron microscopic immunolocalization of cubilin in nonciliated cells of the efferent ducts. Single immunogold labeling of cubilin using 10-nm gold particles shows gold particles at the base of microvilli (MV), in endocytic pits and vesicles (EV) and in early endosomes (EE). Mitochondria (M) are devoid of gold particles. $\mathrm{x} 97,750$ 


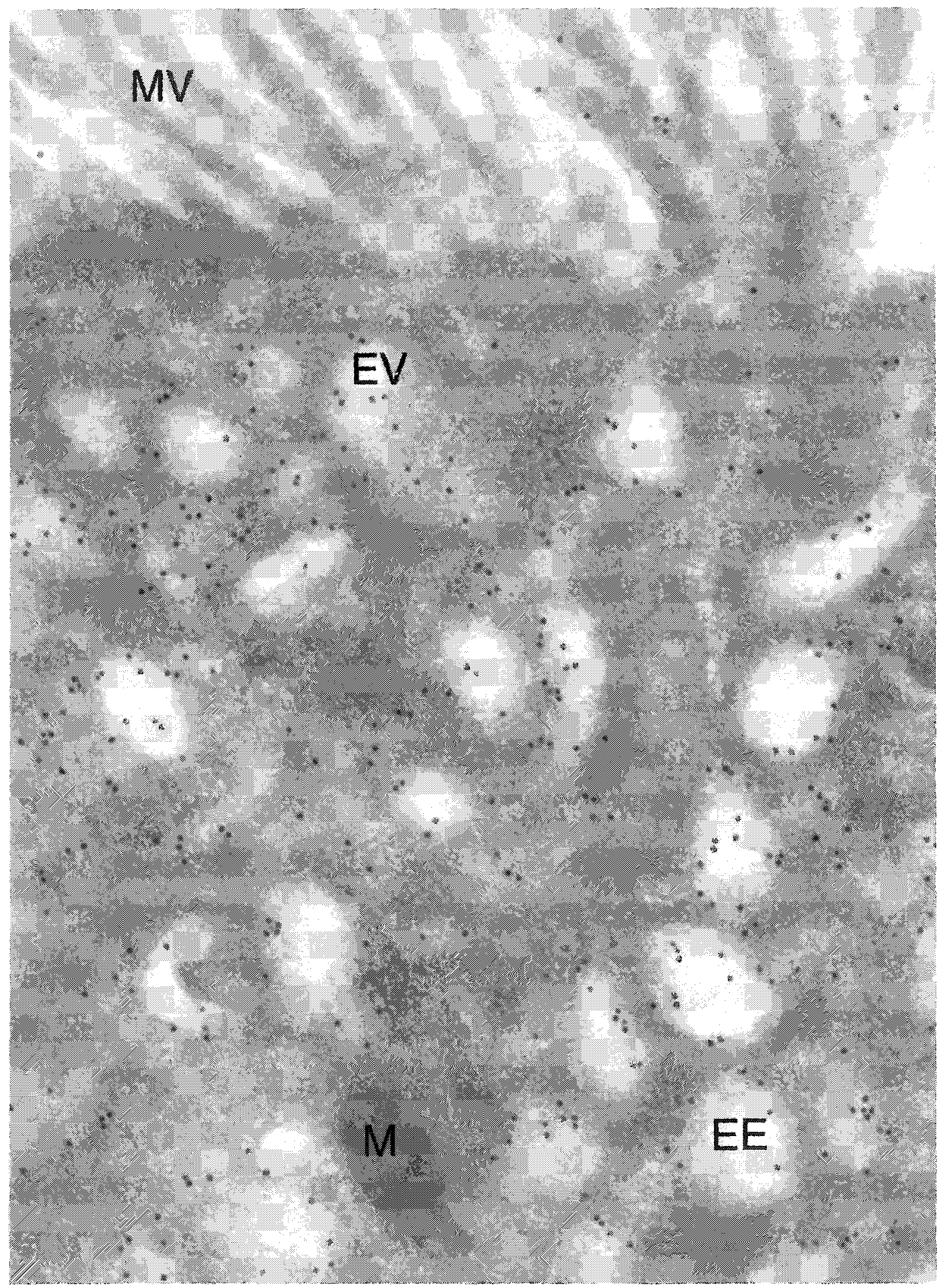


Figure 10. Electron microscopic immunolocalization of cubilin in nonciliated cells of the efferent ducts. Single immunogold labeling of cubilin using 10-nm gold particles shows gold particles present in progressively reduced numbers in endosomes $(\mathrm{E})$, late endosomes (LE) and eventually absent from lysosomes (L) while small vesicles surrounding these larger organelles display significantly more gold particles (arrows). Mitochondria (M) are devoid of gold particles. $\mathrm{x} 108,600$ 


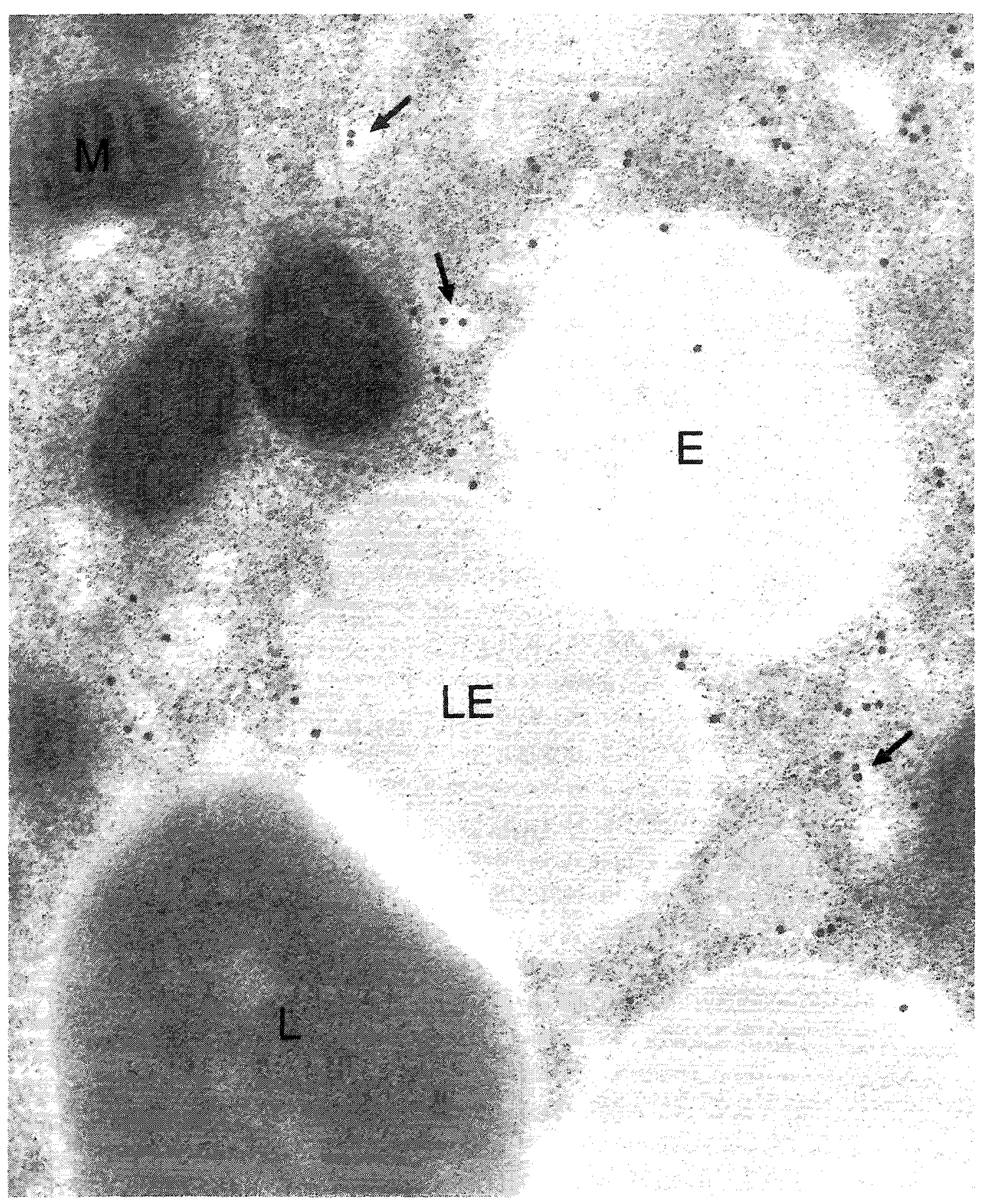


Figure 11. Electron microscopic immunolocalization of cubilin and megalin in nonciliated cells of the efferent ducts. In $\mathrm{A}$ and $\mathrm{B}$, double immunogold labeling of cubilin and megalin, using 10-nm (arrowheads) and 15-nm (arrows) gold particles respectively, shows co-localization of gold particles in endocytic pits (EP), endocytic vesicles (EV) and early endosomes (EE).

A $\times 133,900 ; B \times 157,100$ 


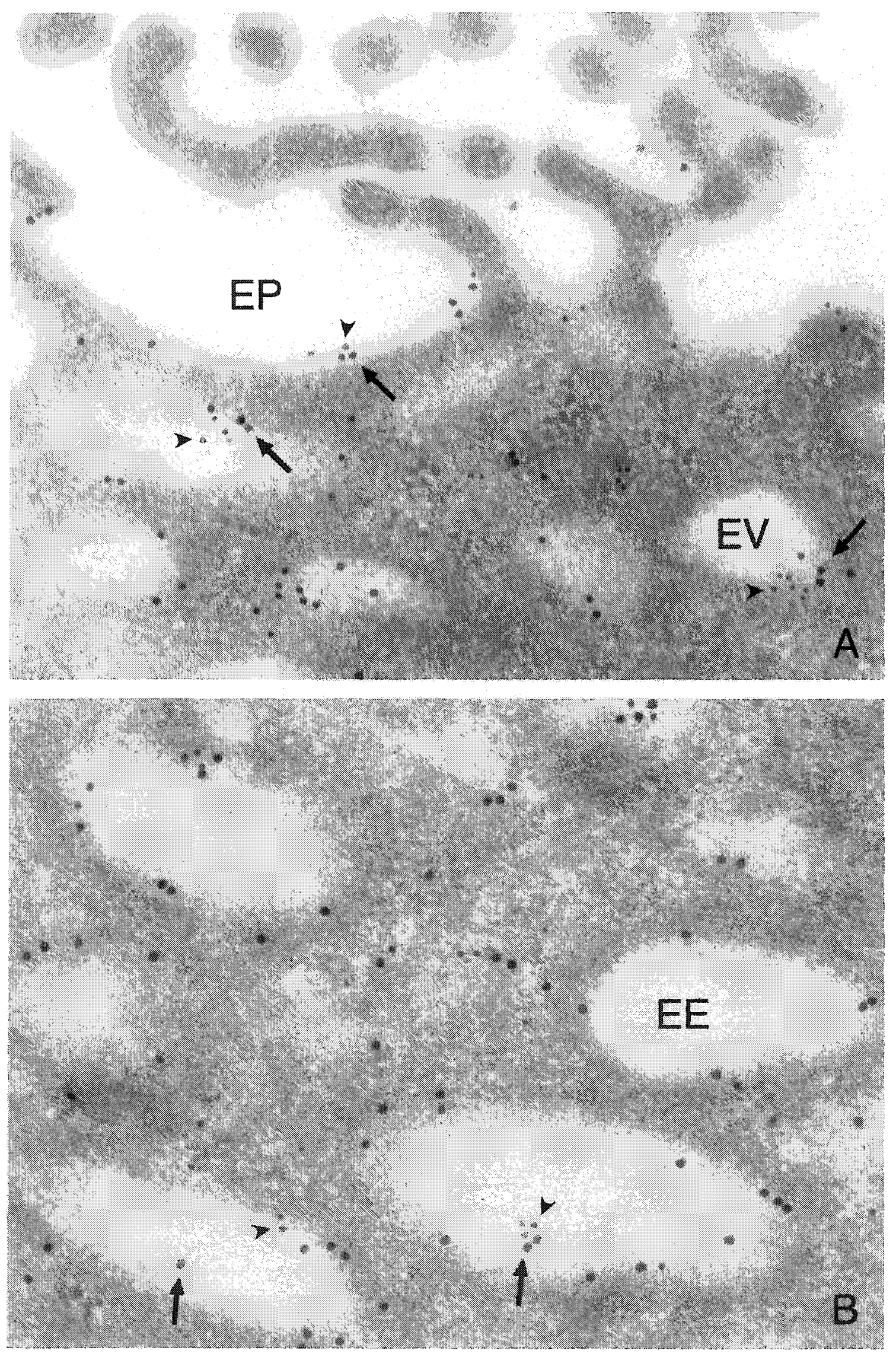


Figure 12. Electron microscopic immunolocalization of cubilin and megalin in nonciliated cells of the efferent ducts. In A, single immunogold labeling of cubilin demonstrates 10-nm gold particles in tubular recycling vesicles (RV) and again absent from lysosomes $(\mathrm{L})$. In $\mathrm{B}$, double immunogold labeling demonstrates a recycling vesicle, with both 10 and 15-nm gold particles, budding off of a late endosomes (LE) or multivesicular body. Arrows indicate 10-nm gold particles and arrowheads indicate 15nm gold particles.

A $x 98,500 ; B \times 86,100$ 


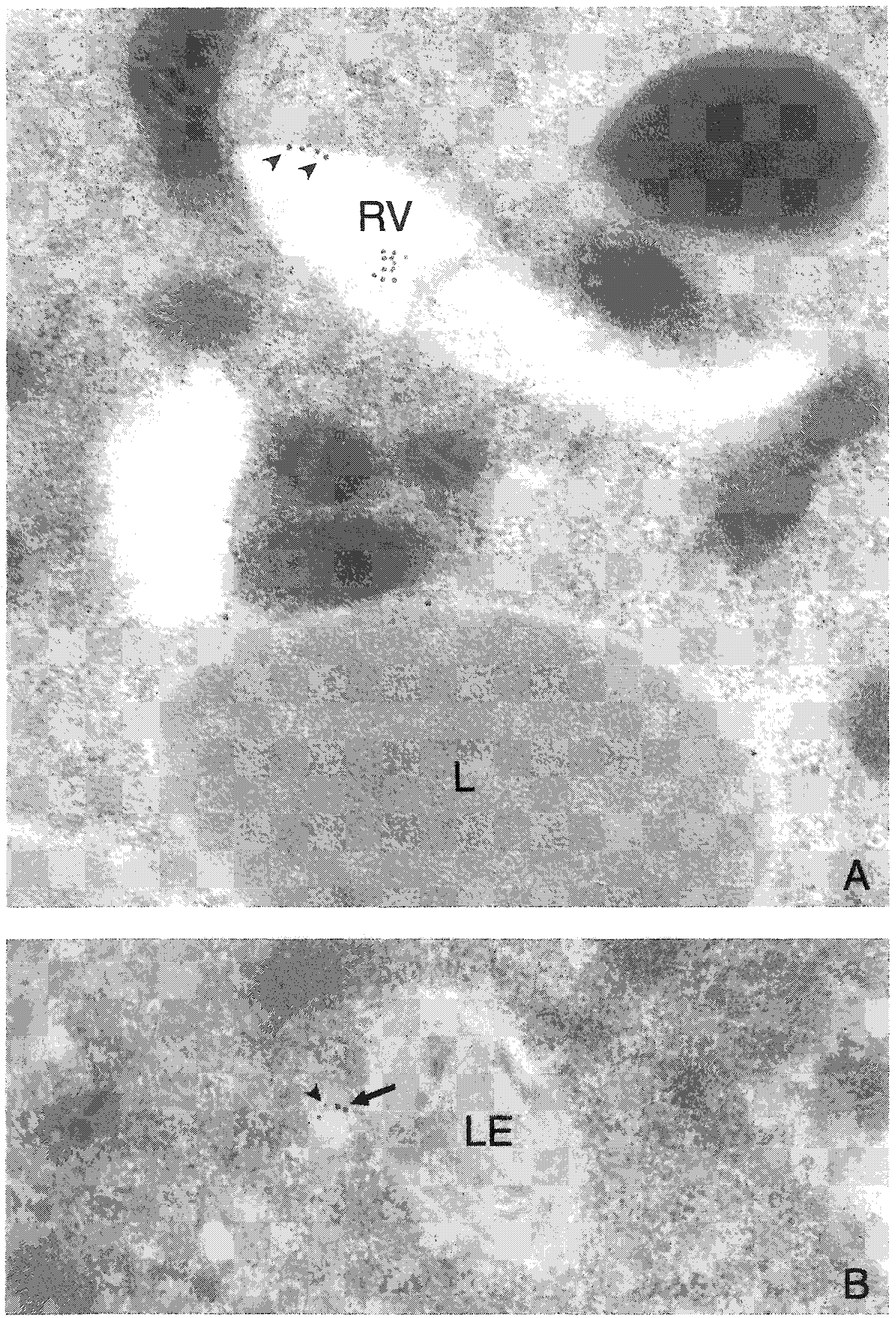


Figure 13. RAP imhibits the endocytic trafficking of cubilin in cells of the efferent ducts. Immunogold labeling of cubilin using 10-nm gold particles following injection of RAP into the efferent ducts $(A)$ resulted in a dramatic decrease in gold particles in endocytic vesicles compared to the control PBS injection (B).

$\mathrm{A}, \mathrm{B} \times 61,000$ 

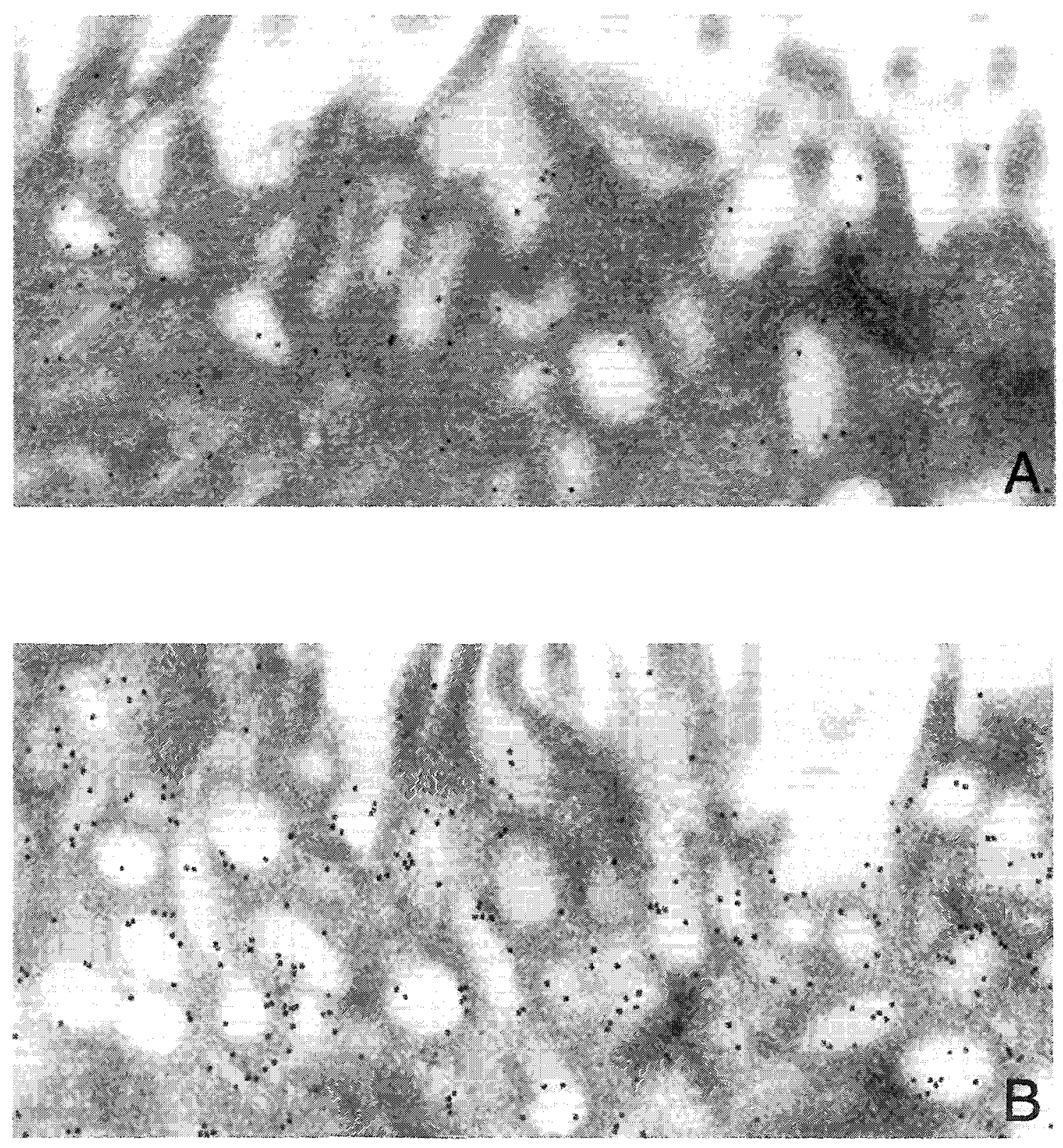
Figure 14. RAP inhibits the endocytic trafficking of cubilin in cells of the vas deferens. Immunogold labeling of cubilin using 10-nm gold particles following injection of RAP into the vas deferens $(A)$ resulted in a dramatic decrease in gold particles in endocytic vesicles compared to the control PBS injection (B).

$\mathrm{A}, \mathrm{B} \times 90,000$ 

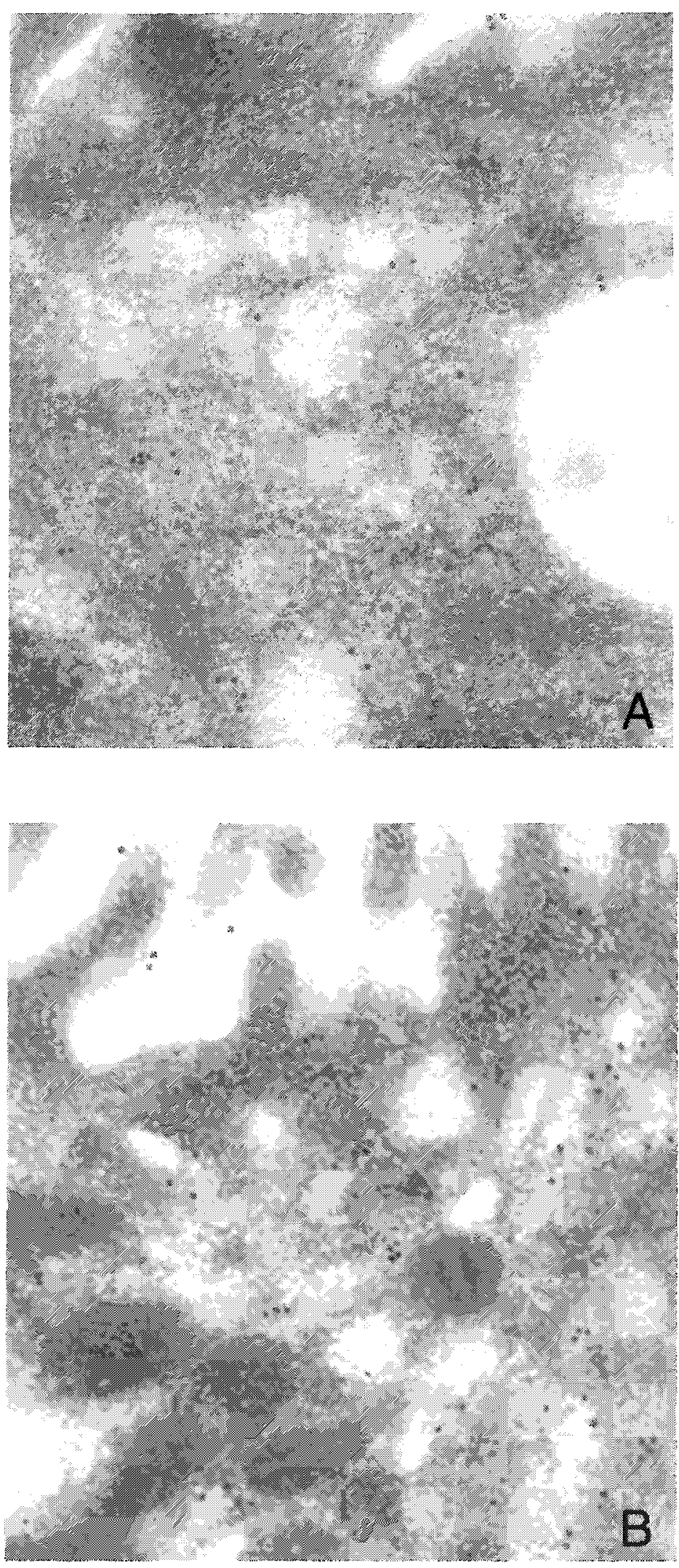
Figure 15. Quantitative analysis of the effect of RAP on in vivo endoeytosis of cubilin by efferent duct and vas deferens epithelial cells. 


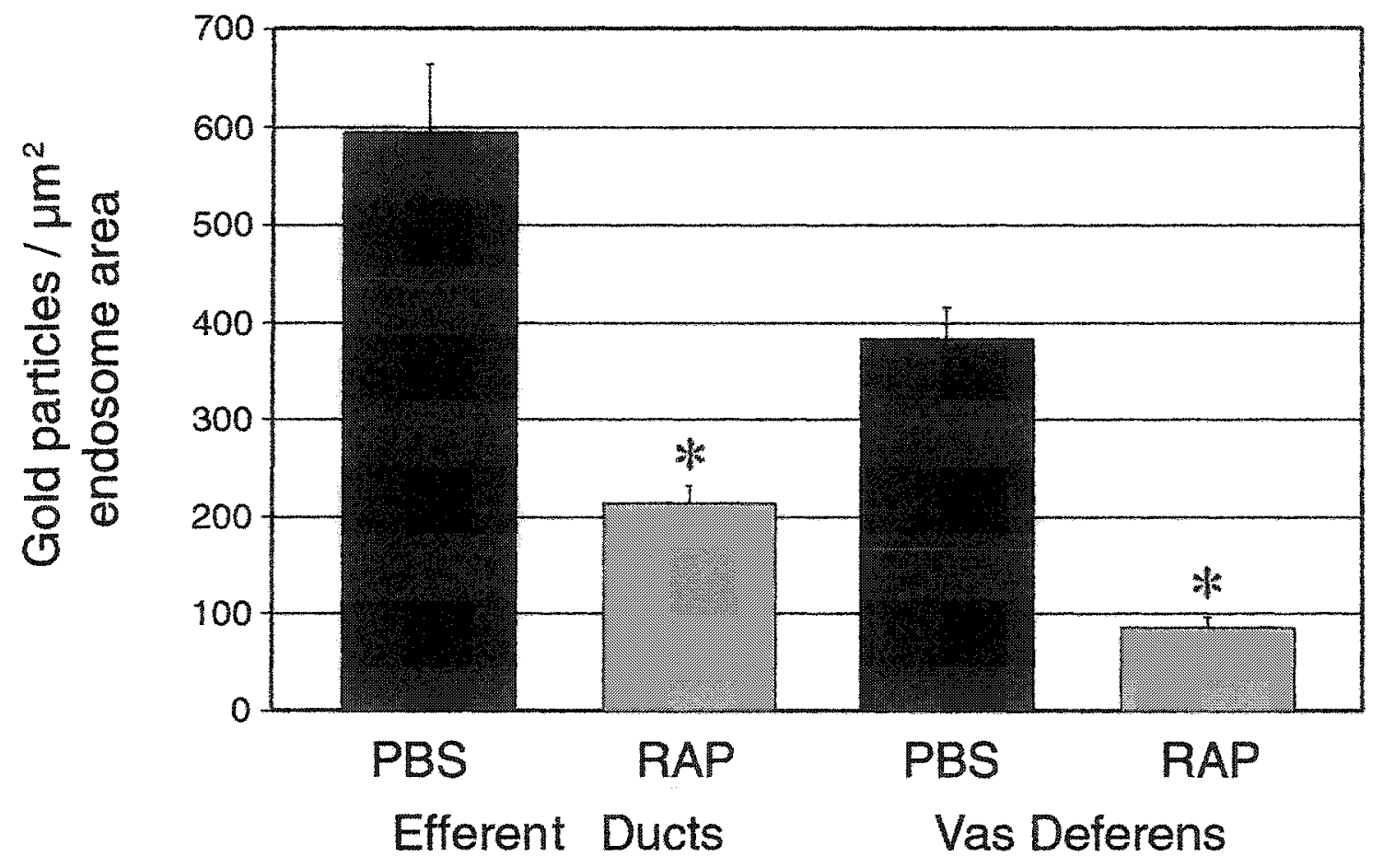




\section{DISCUSSION}

Cubilin and megalin are major endocytic receptors involved in the binding of multiple ligands (Moestrup and Verroust, 2001). The structure of megalin is highlighted by a short intracellular domain, a single transmembrane domain and a large extracellular domain with four clusters of ligand-binding complement-type repeats (Moestrup et al., 1998). Cubilin's ligand binding occurs within its 27 extracellular CUB motifs and although the protein is membrane associated, it lacks a transmembrane domain (Kristiansen et al., 1999). It appears that cubilin is endocytosed along with megalin, and thus essentially amplifies the spectrum of carrier-bound vitamins, lipids and hormones that megalin can internalize. The nutrient-uptake function of these two receptors is essential in adult tissues such as the ileum and kidney where their deficiency can lead to serious illnesses such as Imerslund-Gräsbecks disease in the case of cubilin and renal Fanconi syndrome in the case of megalin (Kozyraki et al., 1998; Norden et al., 2002). In the developing yolk sac, both cubilin and megalin are suggested to play a role in transferring maternal plasma proteins and cholesterol and other lipids to the fetus. In fact, most megalin knockout mice are holoprosencephalous - resulting from either lack of vitamin $A$ or cholesterol - and die shortly after birth (Willnow et al., 1996). A cubilin knockout has not yet been reported.

Previously, megalin has been shown to be the receptor for apo J in the efferent ducts and epididymis (Morales et al., 1996). This finding launched the first question of the present research: whether cubilin, whose localization strongly overlaps with megalin in other absorptive epithelia, is also found in the excurrent ducts of the male reproductive system. RT.PCR established the presence of both cubilin and megalin mRNA in the efferent ducts, corpus and cauda epididymidis and proximal and distal vas deferens. Megalin mRNA was only found unaccompanied in the caput epididymidis. These localization results were supported by western blot analysis. Cell lysates spread along a gel yielded positively labeled anti-cubilin bands in the same tissues as would be predicted from the mRNA localization. 
The light microscopic immunocytochemistry further provided insight into the cellular distribution of cubilin. In the efferent ducts, only nonciliated cells stained for cubilin while ciliated cells did not. These results overlap with the previously reported localization of megalin (Morales et al., 1996). Furthermore, in the corpus and cauda epididymidis as well as in the proximal and middle vas deferens, staining was only seen in the principal cells, again these mirrored previous megalin localization (Morales et al., 1996; Andonian and Hermo, 1999c). However, while megalin uniformly stained the apical aspect of all principal cells, cubilin showed a checkerboard staining of the principal cells. Also - particularly in the corpus and cauda epididymidis - cubilin staining was more diffuse, suggesting a higher amount of cubilin synthesis in these tissues. This, in addition to the apparent graded increase in staining down the epididymis, with maximum staining in the proximal vas deferens, suggest an enhanced role for cubilin as the spermatozoa reach maturity.

Electron microscopy confirmed the subcellular localization of cubilin to the endocytic pathway and co-localized megalin and cubilin to the same endocytic compartments. This is in full agreement with several other studies that have shown similar results in the proximal tubules of the kidney, yolk sac and ileum (Zhai et al., 2000; Bim et al., 2000b; Moestrup et al., 1998; Seethram et al., 1997; Bim et al., 1997; Levine et al., 1984). In addition, both cubilin and megalin are found in endosomes but rarely in lysosomes and we have provided ultrastructural evidence for recycling vesicles budding off of endosomes and presumably heading toward the plasma membrane, further demonstrating the mode of function of the two receptors in the male reproductive tract.

Finally, we used the male rat reproductive system as an in vivo model to examine the functional interaction between megalin and cubilin. To this end, we introduced the megalin $\mathrm{ER}$ chaperone, $\mathrm{RAP}$, into the lumen of the efferent ducts and vas deferens. $\mathrm{RAP}$ is a high affinity antagonist to the in vitro binding of megalin to cubilin (Moestrup et al., 1998), and here we used rap to block the megalin:cubilin interaction in vivo. For the purposes of this experiment it is important to make the following point: RAP is thought to block the binding of megalin and cubilin by interfering with megalin and not 
with cubilin. The evidence for this is threefold: 1. RAP blocks the binding of megalin to all of its ligands (Moestrup et al., 1998; Morales et al., 1996; Cui et al., 1996; Orlando et al., 1997; Zheng et al., 1998; Ranganathan et al., 1999; McCarthy et al., 2002); 2. While it is true that RAP also binds cubilin, this interaction does not to interfere with cubilin's binding to its own ligands (Birn et al., 1997; Kristiansen et al., 1999; Nykjaer et al., 2001); 3. Cubilin's RAP binding region has been localized to CUB domains 1314 while its megalin-binding region is restricted to the $\mathrm{N}$-terminus and only includes CUB domains 1 and 2 (Kristiansen et al., 1999; Yammani et al., 2001). In consequence, we injected RAP into the efferent ducts and vas deferens strictly to interfere with the binding capability of megalin. This distinction is important because we wanted to specifically block the megalin:cubilin binding and not simply effect a generalized blocking of cubilin. Our results yielded a significant decrease in the amount of cubilin in the endocytic compartments when blocking megalin with RAP. This demonstrates, for the first time in the reproductive system, the dependency of cubilin's uptake on megalin. Elsewhere, in vitro assays have confirmed the binding affinity of cubilin and megalin (Moestrup et al., 1998). Megalin antibodies and RAP have both been used to inhibit the uptake of cubilin ligands in cultured cells (Hammad et al, 1999; Kozyraki et al., 1999; Hammad et al., 2000; Zhai et al., 2000; Burmeister et al., 2001; Kozyraki et al., 2001; Nykjaer et al., 2001). As well, megalin knock-outs have shown an internalization defect of cubilin and cubilin ligands (Kozyraki et al., 2001; Burmeister et al., 2001). These previous findings, along with our in vivo results strongly suggest that cubilin binds directly and necessarily to megalin for uptake in the endocytic compartments in the male reproductive tract. Furthermore, the three to four fold decrease in post-RAP cubilin internalization is significant enough to suggest that megalin is the only cubilin receptor and is involved in the sole pathway for internalizing cubilin.

The role of cubilin in the male reproductive system remains unclear. In other tissues cubilin's ligands include intrinsic factor-vitamin $B_{12}$, albumin, transferrin, Apo A-I (and HDL), Ig light chains, hemoglobin and 25(OH) vitamin $\mathrm{D}_{3}$ (Seetharam et al., 1981; Birn et al., 2000b; Kozyraki et al., 2001; Kozyraki et al., 1999; Batuman et al., 1998; Gburek 
et al., 2002; Nykjaer et al., 2001). Intrinsic factor is secreted by the chief cells of the gastric glands and is strictly localized within the digestive tract thus excluding it as a cubilin ligand in the epididymis (Maeda et al., 1995). Albumin, on the other hand, is found in large quantities in testicular and epididymal fluid and although its function remains unknown, it is surely a candidate ligand not only for cubilin but also for megalin, which also shares this ligand (Fouchecourt et al., 2000; Brooks and Higgins, 1980; Cui et al., 1996). Transferrin is a particularly interesting candidate not only because is present in testicular and epididymal fluid but also because it has been found to be endocytosed proximally and much greater distally in the epididymis (Djakiew et al., 1986; Veeramachaneni and Amann, 1991). Cubilin has been recently identified as a transferrin receptor and, as opposed to the ubiquitous transferrin receptor (TfR) which is localized basolaterally in polarized epithelia, cubilin is localized apically and therefore appears to be responsible for transferrin endocytosis in this domain (Odorizzi and Trowbridge, 1997; Anderson et al., 1990; Kozyraki et al., 2001). There is also evidence that apo A-I is an epididymal fluid component, since its mRNA has been localized in the epididymis (Law et al., 1997). The function of apo A-I in the male reproductive system has not been established, but because of its association with apo $\mathrm{J}$ in HDL particles in human plasma, apo A-I may also be a lipid exchanger involved in spermatozoa membrane remodeling.

Cubilin could be the receptor for any number of these and other unknown ligands in the male reproductive tract. It has also been suggested that cubilin may be involved in the uptake of androgen binding protein (ABP) because it has been shown to bind another steroid carrier, the vitamin-D binding protein (Willnow 1999; Nykjaer et al., 2001). This is indeed a possibility given that $\mathrm{ABP}$ is endocytosed by epididymal principal cells by what appears to be a receptor-mediated mechanism (Gerard et al., 1988). Furthermore $A B P$ is immunolocalized in a strikingly similar pattern as cubilin: in the efferent ducts with a strong apical reaction in nonciliated cells, and epididymal principal cells with a more diffuse staining in a checkerboard fashion (Hermo et al., 1998).

Cubilin shares structural similarity with the spermadhesins, a family of secretory proteins of the male reproductive tract. The principal architectural feature of 
spermadhesins is a single CUB domain, a $\sim 100$ amino acid module that is repeated consecutively 27 times in the cubilin polypeptide (Romao et al., 1997; Moestrup et al., 1998). Spermadhesins bind to the acrosomal region of spermatozoa and assist sperm interaction with the zona pellucida at fertilization (Calvete et al., 1996; Sanz et al., 1993; reviewed in Töpfer-Petersen and Calvete, 1995). It is therefore possible that specific CUB domains of the cubilin polypeptide mediate interactions with the membranes of spermatozoa, perhaps important to the process of spermatozoa maturation. In fact, it is even possible that cubilin dissociates completely form the apical plasma membrane of the epithelial cells to associate with spermatozoa in a spermadhesin-like manner. This suggestion arises from the observation that RAP-treated efferent ducts and vas deferens do not display an aggregation of cubilin on their cell surface as might be expected if cubilin is not being internalized. Further investigation would be needed to support this speculation.

Previous analyses of the male reproductive tract have established that megalin is expressed by epithelial cells of the efferent ducts, epididymis and seminal vesicle (Morales et al., 1996; Ranganathan et al., 1999). In the efferent ducts and epididymis at least one protein, apolipoprotein $\mathrm{J}$, is known to be endocytosed through the action of megalin. In the seminal vesicle epithelium, seminal vesicle secretory protein II (SVS-II), a seminal coagulatory protein, is also internalized via megalin. Our present data extend these findings to now include cubilin as a male reproductive tract protein whose endocytosis is mediated by megalin. 


\section{CONCLUSIONS}

As spermatozoa descend through the efferent ducts, the various epididymal comparments and the vas deferens, they are exposed to a specific series of microenvironments composed of differential arrays of proteins and lipids. These molecules are essential for sperm preservation, for binding and transporting hydrophobic compounds and for mediating enzymatic and hormonal activity; all of which are essential processes in sperm maturation. As such, each luminal protein and lipid must be secreted and endocytosed at specific locations along the tract. In this investigation we have discovered, in the efferent ducts in the epididymis and in the vas deferens, a new endocytic receptor involved in the uptake of these luminal compounds: cubilin. Along with the previously identified receptor, megalin, we localized cubilin to the endocytic compartments in the nonciliated cells of the efferent ducts and the principal cells of the epididymis and vas deferens. Furthermore, we demonstrated that cubilin binds megalin in a manner which is essential for its endocytosis. As such, cubilin might extend the ligand clearing abilities of megalin in the male reproductive tract and play an important role in sperm membrane remodeling and in sperm maturation. 


\section{ABBREVIATIONS}

aa

$\mathrm{ABP}$

ANOVA

Apo

ApoER2

ATP

$\mathrm{bp}$

BSA

CCSP

cDNA

CUB

CURL

$\mathrm{DAB}$

DNA

dNTP

EGF

EM

ER

gp280

gp330

GPI

GST

HDL

HRP

IDL

$\mathrm{IF}-\mathrm{B}_{12}$

$\operatorname{Ig}$

$\mathrm{kDa}$

LDL

LDL-R amino acid

androgen binding protein

analysis of variance

apolipoprotein

apolipoprotein $\mathrm{E}$ receptor 2

adenosine triphosphate

base pair

bovine serum albumin

clara cell secretory protein

complementary deoxyribonucleic acid

complement $\mathrm{C} 1 \mathrm{r} / \mathrm{C} 1 \mathrm{~s}$, uegf and bone morphogenic protein 1

compartment for uncoupling receptors from ligands

diamino-benzidine tetra-hydrochloride

deoxyribonucleic acid

deoxynucleotide-triphosphate

epidermal growth factor

electron microscope

endoplasmic reticulum

glycoprotein 280

glycoprotein 330

glycosylphosphatidyl-inositol

glutathione s-transferase

high density lipoprotein

horse radish peroxidase

intermediate density lipoprotein

intrinsic factor-vitamin $B_{12}$

immunoglobulin

kiloDalton

low density lipoprotein

low density lipoprotein receptor 
LRP low density lipoprotein receptor-related protein

LRP-2 low density lipoprotein receptor-related protein 2

mRNA messenger ribonucleic acid

PBS phosphate buffer saline

PCR polymerase chain reaction

PMSF phenylmethylsulfonyl fluoride

RAP receptor associated protein

RNA ribonucleic acid

RT-PCR reverse transcriptase-polymerase chain reaction

SGP-1 sulfated glycoprotein-1

SGP-2 sulfated glycoprotein-2

SHH sonic hedgehog

SORLA-1 Sorting protein-related receptor containing LDLR class A repeats

SVS-II seminal vesicle secretory protein II

Taq Thermus aquaticus

TBS tris buffer saline

TfR transferrin receptor

VLDL very low density lipoprotein 


\section{REFERENCES}

Adamali HI, Hermo L. Apical and narrow cells are distinct cell types differing in their structure, distribution, and functions in the adult rat epididymis. I Androl. 1996; $17(3): 208-22$.

Aminoff M, Carter JE, Chadwick RB, Johnson C, Grasbeck R, Abdelaal MA, Broch

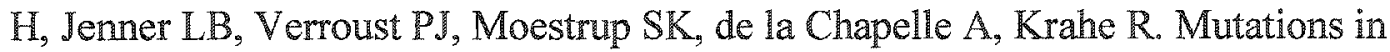
CUBN, encoding the intrinsic factor-vitamin $\mathrm{B} 12$ receptor, cubilin, cause hereditary megaloblastic anaemia 1. Nat Genet. 1999; 21(3):309-13.

Anderson GJ, Powell LW, Halliday JW. Transferrin receptor distribution and regulation in the rat small intestine. Effect of iron stores and erythropoiesis. Gastroenterology. 1990; 98:576-85.

Andonian S, Hermo L. Immunocytochemical localization of the Ya, Yb1, Yc, Yf, and Yo subunits of glutathione S-transferases in the cauda epididymidis and vas deferens of adult rats. J Androl. 1999a; 20(1):145-57.

Andonian S, Hermo L. Principal cells of the vas deferens are involved in water transport and steroid synthesis in the adult rat. J Androl. 1999b; 20(1):158-76.

Andonian S, Hermo L. Cell- and region-specific localization of lysosomal and secretory proteins and endocytic receptors in epithelial cells of the cauda epididymidis and vas deferens of the adult rat. I Androl. 1999c; 20(3):415-29.

Argraves WS. Members of the low density lipoprotein receptor family control diverse physiological processes. Front Biosci. 2001; 6:D406-16.

Aveldano MI, Rotstein NP, Vermouth NT. Lipid remodelling during epididymal maturation of rat spermatozoa. Enrichment in plasmenylcholines containing longchain polyenoic fatty acids of the $\mathrm{n}-9$ series. Biochem J. 1992; 283 ( Pt 1):235-41.

Avila EM, Holdsworth G, Sasaki N, Jackson RL, Harmony JA. Apoprotein E suppresses phytohemagglutinin-activated phospholipid turnover in peripheral blood mononuclear cells. J Biol Chem. 1982; $257(10): 5900-9$.

Badran HH, Hermo LS. Expression and regulation of aquaporins 1, 8, and 9 in the testis, efferent ducts, and epididymis of adult rats and during postnatal development. $J$ Androl. 2002; 23(3):358-73.

Batuman V, Verroust PJ, Navar GL, Kaysen JH, Goda FO, Campbell WC, Simon E, Pontillon $\mathrm{F}$, Lyles M, Bruno J, Hammond TG. Myeloma light chains are ligands for cubilin (gp280). Am J Physiol. 1998; 275(2 Pt 2):F246-54. 
Bedford JM, Calvin HI. The occurrence and possible functional significance of -S-Scrosslinks in sperm heads, with particular reference to eutherian mammals. J Exp Zool. 1974a; 188(2):137-55.

Bedford JM, Calvin HI. Changes in -S-S- linked structures of the sperm tail during epididymal maturation, with comparative observations in sub-mammalian species. J Exp Zool. 1974b; 187(2):181-204.

Bedford JM, Nicander L. Ultrastructural changes in the acrosome and sperm membranes during maturation of spermatozoa in the testis and epididymis of the rabbit and monkey. J Anat. 1971; 108(3):527-43.

Birn H, Verroust PJ, Nexo E, Hager H, Jacobsen C, Christensen EI, Moestrup SK. Characterization of an epithelial approximately $460-\mathrm{kDa}$ protein that facilitates endocytosis of intrinsic factor-vitamin B12 and binds receptor-associated protein. $J$ Biol Chem. 1997; 272(42):26497-504.

Birn H, Vorum H, Verroust PJ, Moestrup SK, Christensen EI. Receptor-associated protein is important for normal processing of megalin in kidney proximal tubules. $\mathrm{J}$ Am Soc Nephrol. 2000a; 11(2):191-202.

Birn H, Fyfe JC, Jacobsen C, Mounier F, Verroust PJ, Orskov H, Willnow TE, Moestrup SK, Christensen EI. Cubilin is an albumin binding protein important for renal tubular albumin reabsorption. J Clin Invest. 2000b; 105(10):1353-61.

Boyles JK, Zoellner CD, Anderson LJ, Kosik LM, Pitas RE, Weisgraber KH, Hui DY, Mahley RW, Gebicke-Haerter PJ, Ignatius MJ, Shooter EM. A role for apolipoprotein E, apolipoprotein A-I, and low density lipoprotein receptors in cholesterol transport during regeneration and remyelination of the rat sciatic nerve. $J$ Clin Invest. 1989; 83(3):1015-31.

Bork P, Beckmann G. The CUB domain. A widespread module in developmentally regulated proteins. J Mol Biol. 1993; 231(2):539-45.

Broch H, Imerslund O, Monn E, Hovig T, Seip M. Imerslund-Grasbeck anemia. A long-term follow-up study. Acta Paediatr Scand. 1984; 73(2):248-53.

Brooks DE, Higgins SJ. Characterization and androgen-dependence of proteins associated with luminal fluid and spermatozoa in the rat epididymis. J Reprod Fertil. 1980; 59: 363-75.

Brown D, Breton S. H(+)V-ATPase-dependent luminal acidification in the kidney collecting duct and the epididymis/vas deferens: vesicle recycling and transcytotic pathways. J Exp Biol. 2000; 203 Pt 1:137-45. 
Brown D, Verbavatz JM, Valenti G, Lui B, Sabolic I. Localization of the CHIP28 water channel in reabsorptive segments of the rat male reproductive tract. Eur J Cell Biol. 1993; 61(2):264-73.

Bu G, Rennke S. Receptor-associated protein is a folding chaperone for low density lipoprotein receptor-related protein. J Biol Chem. 1996; 271(36):22218-24.

Burkey BF, Stuart WD, Harmony JA. Hepatic apolipoprotein J is secreted as a lipoprotein. J Lipid Res. 1992; 33(10):1517-26.

Burmeister R, Boe IM, Nykjaer A, Jacobsen C, Moestrup SK, Verroust P, Christensen EI, Lund J, Willnow TE. A two-receptor pathway for catabolism of Clara cell secretory protein in the kidney. J Biol Chem. 2001; 276:13295-301.

Calvete JJ, Carrera E, Sanz L, Topfer-Petersen E. Boar spermadhesins AQN-1 and AQN-3: oligosaccharide and zona pellucida binding characteristics. Biol Chem. 1996; 377(7-8):521-7.

Chen SH, Habib G, Yang CY, Gu ZW, Lee BR, Weng SA, Silberman SR, Cai SI, Deslypere JP, Rosseneu M, et al. Apolipoprotein B-48 is the product of a messenger RNA with an organ-specific in-frame stop codon. Science. 1987; 238(4825):363-6.

Cheng-Chew SB, Chew EC, Yang L, Leung PY, Yam HF, Jiao RJ, Zhai ZH. Ultrastructural study on the development of the rat [correction of mouse] spermatocyte nuclear matrix during epididymal maturation. In Vivo. 1994; 8(3):3636.

Chiang C, Litingtung $\mathrm{Y}$, Lee E, Young KE, Corden JL, Westphal H, Beachy PA. Cyclopia and defective axial patterning in mice lacking Sonic hedgehog gene function. Nature. 1996; 383(6599):407-13.

Choi-Miura NH, Thara Y, Fukuchi K, Takeda M, Nakano Y, Tobe T, Tomita M. SP. 40,40 is a constituent of Alzheimer's amyloid. Acta Neuropathol (Berl). 1992; $83(3): 260-4$

Christensen EI, Birn H. Megalin and cubilin: synergistic endocytic receptors in renal proximal tubule. Am J Physiol Renal Physiol. 2001; 280(4):F562-73.

Clemont Y, Flannery J. Mitotic activity in the epithelium of the epididymis in young and old adult rats. Biol Reprod. 1970; 3(3):283-92.

Clulow J, Jones RC, Hansen LA, Man SY. Fluid and electrolyte reabsorption in the ductuli efferentes testis. I Reprod Fertil Suppl. 1998; 53:1-14.

Cooper ER, Jackson $H$. The vasa efferentia in the rat and mouse. J Reprod Fertil. 1972; 28(2):317-9. 
Cooper TG. Interactions between epidiymal secretions and spermatozoa. I Reprod Fertil Suppl. 1998; 53:119-36.

Corder EH, Saunders AM, Strittmatter WJ, Schmechel DE, Gaskell PC, Small GW, Roses AD, Haines JL, Pericak-Vance MA. Gene dose of apolipoprotein E type 4 allele and the risk of Alzheimer's disease in late onset families. Science. 1993; 261(5123):921-3.

Crider-Pirkle S, Billingsley P, Faust C, Hardy DM, Lee V, Weitlauf H. Cubilin, a binding partner for galectin-3 in the murine utero-placental complex. J Biol Chem. $2002 ; 277(18): 15904-12$.

Cross NL. Role of cholesterol in sperm capacitation. Biol Reprod. 1998; 59:7-11. Cui S, Verroust PJ, Moestrup SK, Christensen EI. Megalin/gp330 mediates uptake of albumin in renal proximal tubule. Am J Physiol. 1996; 271 : F900-7.

Dacheux JL, Druart X, Fouchecourt S, Syntin P, Gatti JL, Okamura N, Dacheux F. Role of epididymal secretory proteins in sperm maturation with particular reference to the boar. J Reprod Fertil Suppl. 1998; 53:99-107.

de Silva HV, Stuart WD, Duvic CR, Wetterau JR, Ray MJ, Ferguson DG, Albers HW, Smith WR, Harmony JA. A 70-kDa apolipoprotein designated ApoJ is a marker for subclasses of human plasma high density lipoproteins. I Biol Chem. 1990; 265:13240-7.

Djakiew D, Griswold MD, Lewis DM, Dym M. Micropuncture studies of receptormediated endocytosis of transferrin in the rat epididymis. Biol Reprod. 1986; 34:6919.

Dyer CA, Curtiss LK. Apoprotein E-rich high density lipoproteins inhibit ovarian androgen synthesis. J Biol Chem. 1988; 263(22):10965-73.

Flickinger CJ, Bush LA, Howards SS, Herr JC. Distribution of leukocytes in the epithelium and interstitium of four regions of the Lewis rat epididymis. Anat Rec. $1997 ; 248(3): 380-90$.

Frank PG, Marcel YL. Apolipoprotein A-I: structure-function relationships. J Lipid Res. 2000; 41(6):853-72.

Fouchecourt S, Metayer S, Locatelli A, Dacheux F, Dacheux J. Stallion epididymal fluid proteome: qualitative and quantitative characterization; secretion and dynamic changes of major proteins. Biol Reprod. 2000; 62(6):1790-803. 
Gburek J, Verroust PJ, Willnow TE, Fyfe JC, Nowacki W, Jacobsen C, Moestrup \$K, Christensen EI. Megalin and cubilin are endocytic receptors involved in renal clearance of hemoglobin. J Am Soc Nephrol. 2002; 13(2):423-30.

Gerard H, Gueant JL, Gerard A, Fremont S, el Harate A, Nicolas JP, Grignon G. Endocytosis of the androgen-binding-protein (ABP) by the principal cells of rat epididymis. Reprod Nutr Dev. 1988; 28:1257-66.

Gräsbeck R, Gordin RKI, Kihlbäck B. Selective vitamin B12 malabsorption and proteinuria in young people. Acta Med Scand. 1960; 167:289-96.

Griswold MD, Roberts K, Bishop P. Purification and characterization of a sulfated glycoprotein secreted by Sertoli cells. Biochemistry. 1986; 25(23):7265-70.

Hall JC, Hadley J, Doman T. Correlation between changes in rat sperm membrane lipids, protein, and the membrane physical state during epididymal maturation. $J$ Androl. 1991; 12(1):76-87.

Hamilton, DW. Structure and function of the epithelium lining the ductuli efferentes, ductus epididymis and ductus deferens in the rat. In: Handbook of Physiology. Greep RO, Astwood EB, Eds. American Physiological Society, Washington, 1975, pp.259301.

Hammad SM, Ranganathan S, Loukinova E, Twal WO, Argraves WS. Interaction of apolipoprotein J-amyloid beta-peptide complex with low density lipoprotein receptorrelated protein-2/megalin. A mechanism to prevent pathological accumulation of amyloid beta-peptide. J Biol Chem. 1997; 272:18644-9.

Hammad SM, Stefansson S, Twal WO, Drake CJ, Fleming P, Remaley A, Brewer HB $\mathrm{Jr}$, Argraves WS. Cubilin, the endocytic receptor for intrinsic factor-vitamin B(12) complex, mediates high-density lipoprotein holoparticle endocytosis. Proc Natl Acad Sci U S A. 1999; 96:10158-63.

Hammad SM, Barth JL, Knaak C, Argraves WS. Megalin acts in concert with cubilin to mediate endocytosis of high density lipoproteins. J Biol Chem. 2000; 275:12003-8.

Hermo L, Morales C. Endocytosis in nonciliated epithelial cells of the ductuli efferentes in the rat. Am J Anat. 1984; 171(1):59-74.

Hermo L, de Melo V. Endocytic apparatus and transcytosis in epithelial cells of the vas deferens in the rat. Anat Rec. 1987; 217(2):153-63.

Hermo L, Robaire B. Epididymal cell types and their functions. In: The Epididymis: From Molecules to Clinical Practice. Robaire B and Hinton B, Eds., Klewer Academic/Plenum Publishers, New York, 2002, pp 81-102. 
Hermo L, Clermont Y, Morales C. Fluid-phase and adsorptive endocytosis in ciliated epithelial cells of the rat ductuli efferentes. Anat Rec. 1985; 211(3):285-94.

Hermo L, Dworkin J, Oko R. Role of epithelial clear cells of the rat epididymis in the disposal of the contents of cytoplasmic droplets detached from spermatozoa. Am J Anat. 1988; 183(2):107-24.

Hermo L, Wright J, Oko R, Morales CR. Role of epithelial cells of the male excurrent duct system of the rat in the endocytosis or secretion of sulfated glycoprotein-2 (clusterin). Biol Reprod. 1991a; 44:1113-31.

Hermo L, Green $\mathrm{H}$, Clermont Y. Golgi apparatus of epithelial principal cells of the epididymal initial segment of the rat: structure, relationship with endoplasmic reticulum, and role in the formation of secretory vesicles. Anat Rec. 1991b; 229(2):159-76.

Hermo L, Oko R, Robaire B. Epithelial cells of the epididymis show regional variations with respect to the secretion of endocytosis of immobilin as revealed by light and electron microscope immunocytochemistry. Anat Rec. 1992; 232(2):202-20.

Hermo L, Oko R, Morales CR. Secretion and endocytosis in the male reproductive tract: a role in sperm maturation. Int Rev Cytol. 1994; 154:106-89.

Hermo L, Barin K, Oko R. Androgen binding protein secretion and endocytosis by principal cells in the adult rat epididymis and during postnatal development. J Androl. $1998 ; 19: 527-41$.

Hermo L, Adamali HI, Andonian S. Immunolocalization of CA II and H+ V-ATPase in epithelial cells of the mouse and rat epididymis. J Androl. 2000; 21(3):376-91.

Hermo L, Badran $\mathrm{H}$, Andonian S. The structural organization and functions of the epithelium of the vas deferens. In: The Epididymis: From Molecules to Clinical Practice. Robaire B and Hinton B, Eds., Klewer Academic/Plenum Publishers, New York, 2002, pp 233-250.

Hinton BT, Palladino MA. Epididymal epithelium: its contribution to the formation of a luminal fluid microenvironment. Microsc Res Tech. 1995; 30(1):67-81.

Holland MK, Nixon B. The specificity of epididymal secretory proteins. J Reprod Fertil Suppl. 1998; 53:197-210.

Hooper P, Smythe E, Richards RC, Howard CV, Lynch RV, Lewis-Jones DI. Total number of immunocompetent cells in the normal rat epididymis and after vasectomy. J Reprod Fertil. 1995; 104(2):193-8. 
Huang LS, Voyiaziakis E, Markenson DF, Sokol KA, Hayek T, Breslow JL. apo B gene knockout in mice results in embryonic lethality in homozygotes and neural tube defects, male infertility, and reduced HDL cholesterol ester and apo A-I transport rates in heterozygotes. J Clin Invest. 1995; 96(5):2152-61.

Huang LS, Voyiaziakis E, Chen HL, Rubin EM, Gordon JW. A novel functional role for apolipoprotein B in male infertility in heterozygous apolipoprotein B knockout mice. Proc Natl Acad Sci U S A. 1996; 93(20):10903-7.

Hussain MM. Structural, biochemical and signaling properties of the low-density lipoprotein receptor gene family. Front Biosci. 2001; 6:D417-28.

Igdoura SA, Hermo L, Rosenthal A, Morales CR. Nonciliated cells of the rat efferent ducts endocytose testicular sulfated glycoprotein-1 (SGP-1) and synthesize SGP-1 derived sap osins. Anat Rec. 1993; 235(3):411-24.

Igdoura SA, Hermo L, Morales CR. Sulfated glycoprotein-2 synthesized by nonciliated cells of the efferent ducts is targeted to the lysosomal compartment. Microsc Res Tech. 1994; 29:468-80.

Ilio KY, Hess RA. Structure and function of the ductuli efferentes: a review. Microsc Res Tech. 1994; 29(6):432-67.

Jenne DE, Lowin B, Peitsch MC, Bottcher A, Schmitz G, Tschopp J. Clusterin (complement lysis inhibitor) forms a high density lipoprotein complex with apolipoprotein A-I in human plasma. J Biol Chem. 1991; 266(17):11030-6.

Jin YZ, Bannai S, Dacheux F, Dacheux JL, Okamura N. Direct evidence for the secretion of lactoferrin and its binding to sperm in the porcine epididymis. Mol Reprod Dev. 1997; 47(4):490-6.

Jones R. Plasma membrane structure and remodelling during sperm maturation in the epididymis. J Reprod Fertil Suppl. 1998; 53:73-84.

Jones R. Plasma membrane composition and organization during maturation of spermatozoa in the epididymis. In: The Epididymis: From Molecules to Clinical Practice. Robaire B and Hinton B, Eds., Klewer Academic/Plenum Publishers, New York, 2002, pp 405-416.

Jones R, von Glos KI, Brown CR. Changes in the protein composition of rat spermatozoa during maturation in the epididymis. J Reprod Fertil. 1983; 67(2):299306.

Jones RC, Jurd KM. Structural differentiation and fluid reabsorption in the ductuli efferentes testis of the rat. Aust J Biol Sci. 1987; 40(1):79-90. 
Kennedy SW, Heidger PM Jr. Fine structural studies of the rat vas deferens. Anat Rec. $1979 ; 194(1): 159-79$.

Kesaniemi YA, Witztum JL, Steinbrecher UP. Receptor-mediated catabolism of low density lipoprotein in man. Quantitation using glucosylated low density lipoprotein. J Clin Invest. 1983; 71(4):950-9.

Kibbey RG, Rizo J, Gierasch LM, Anderson RG. The LDL receptor clustering motif interacts with the clathrin terminal domain in a reverse turn conformation. J Cell Biol. 1998; 142(1):59-67.

Kirchhoff C. Molecular characterization of epididymal proteins. Rev Reprod. 1998; $3(2): 86-95$.

Klinefelter, GR, Hess RA. Toxicity of the excurrent ducts and accessory organs in the male. In: Reproductive and developmental toxicology. Korach KS, Ed., Marcel Dekker, Inc., New York, 1998, pp 553-591.

Kounnas MZ, Haudenschild CC, Strickland DK, Argraves WS. Immunological localization of glycoprotein 330 , low density lipoprotein receptor related protein and $39 \mathrm{kDa}$ receptor associated protein in embryonic mouse tissues. In Vivo. 1994; $8(3): 343-51$.

Kozyraki R. Cubilin, a multifunctional epithelial receptor: an overview. J Mol Med. 2001; 79(4):161-7.

Kozyraki R, Kristiansen M, Silahtaroglu A, Hansen C, Jacobsen C, Tommerup N, Verroust PJ, Moestrup SK. The human intrinsic factor-vitamin B12 receptor, cubilin: molecular characterization and chromosomal mapping of the gene to $10 \mathrm{p}$ within the autosomal recessive megaloblastic anemia (MGA1) region. Blood. 1998; 91:3593600 .

Kozyraki R, Fyfe J, Kristiansen M, Gerdes C, Jacobsen C, Cui S, Christensen EI, Aminoff M, de la Chapelle A, Krahe R, Verroust PJ, Moestrup SK. The intrinsic factor-vitamin B12 receptor, cubilin, is a high-affinity apolipoprotein A-I receptor facilitating endocytosis of high-density lipoprotein. Nat Med. 1999; 5:656-61.

Kozyraki R, Fyfe J, Verroust PJ, Jacobsen C, Dautry-Varsat A, Gburek J, Willnow TE, Christensen EI, Moestrup SK. Megalin-dependent cubilin-mediated endocytosis is a major pathway for the apical uptake of transferrin in polarized epithelia. Proc Natl Acad Sci U S A. 2001; 98:12491-6.

Kristiansen M, Kozyraki R, Jacobsen C, Nexo E, Verroust PJ, Moestrup SK. Molecular dissection of the intrinsic factor-vitamin B12 receptor, cubilin, discloses regions important for membrane association and ligand binding. J Biol Chem. 1999; 274(29):20540-4. 
Kristiansen M, Aminoff M, Jacobsen C, de La Chapelle A, Krahe R, Verroust PJ, Moestrup SK. Cubilin P1297L mutation associated with hereditary megaloblastic anemia 1 causes impaired recognition of intrinsic factor-vitamin $B(12)$ by cubilin. Blood. 2000; 96(2):405-9.

Lakoski KA, Carron CP, Cabot CL, Saling PM. Epididymal maturation and the acrosome reaction in mouse sperm: response to zona pellucida develops coincident with modification of M42 antigen. Biol Reprod. 1988; 38(1):221-33.

Law GL, McGuinness MP, Linder CC, Griswold MD. Expression of apolipoprotein E mRNA in the epithelium and interstitium of the testis and the epididymis. J Androl. $1997 ; 18(1): 32-42$.

Legare C, Berube B, Boue F, Lefievre L, Morales CR, El-Alfy M, Sullivan R. Hamster sperm antigen P26h is a phosphatidylinositol-anchored protein. Mol Reprod Dev. 1999; 52(2):225-33.

Leheste JR, Rolinski B, Vorum H, Hilpert J, Nykjaer A, Jacobsen C, Aucouturier P, Moskaug JO, Otto A, Christensen EI, Willnow TE. Megalin knockout mice as an animal model of low molecular weight proteinuria. Am J Pathol. 1999; 155(4):136170 .

Levine JS, Allen RH, Alpers DH, Seetharam B. Immunocytochemical localization of the intrinsic factor-cobalamin receptor in dog-ileum: distribution of intracellular receptor during cell maturation. J Cell Biol. 1984; 98(3):1111-8.

Levine N, Marsh DJ. Micropuncture studies of the electrochemical aspects of fluid and electrolyte transport in individual seminiferous tubules, the epididymis and the vas deferens in rats. J Physiol. 1971; 213(3):557-70.

Lloyd JB. Cell physiology of the rat visceral yolk sac: a study of pinocytosis and lysosome function. Teratology. 1990; 41(4):383-93.

Lundgren S, Carling T, Hjalm G, Juhlin C, Rastad J, Pihlgren U, Rask L, Akerstrom G, Hellman P. Tissue distribution of human gp330/megalin, a putative $\mathrm{Ca}(2+)-$ sensing protein. J Histochem Cytochem. 1997; 45(3):383-92.

Maeda M, Asahara S, Nishi T, Mushiake S, Oka T, Shimada S, Chiba T, Tohyama M, Futai $M$. The rat intrinsic factor gene: its 5 '-upstream region and chief cell-specific transcription. J Biochem (Tokyo). 1995; 117:1305-11.

Mahley RW, Innerarity TL, Rall SC Jr, Weisgraber KH. Plasma lipoproteins: apolipoprotein structure and function. J Lipid Res. 1984; 25(12):1277-94. 
McCarthy RA, Barth IL, Chintalapudi MR, Knaak C, Argraves WS. Megalin functions as an endocytic sonic hedgehog receptor. J Biol Chem. 2002;

$277(28): 25660-7$.

McDonald JF, Nelsestuen GL. Potent inhibition of terminal complement assembly by clusterin: characterization of its impact on C9 polymerization. Biochemistry. 1997; $36(24): 7464-73$.

Moestrup SK, Verroust PJ. Megalin- and cubilin-mediated endocytosis of proteinbound vitamins, lipids, and hormones in polarized epithelia. Annu Rev Nutr. 2001; $21: 407-28$

Moestrup SK, Bim H, Fischer PB, Petersen CM, Verroust PJ, Sim RB, Christensen EI, Nexo E. Megalin-mediated endocytosis of transcobalamin-vitamin-B12 complexes suggests a role of the receptor in vitamin-B12 homeostasis. Proc Natl Acad Sci U S A. 1996;93(16):8612-7.

Moestrup SK, Kozyraki R, Kristiansen M, Kaysen JH, Rasmussen HH, Brault D, Pontillon F, Goda FO, Christensen EI, Hammond TG, Verroust PJ. The intrinsic factor-vitamin $B 12$ receptor and target of teratogenic antibodies is a megalin-binding peripheral membrane protein with homology to developmental proteins. J Biol Chem. $1998 ; 273: 5235-42$.

Morales C, Hermo L. Demonstration of fluid-phase endocytosis in epithelial cells of the male reproductive system by means of horseradish peroxidase-colloidal gold complex. Cell Tissue Res. 1983;230(3):503-10.

Morales CR, Igdoura SA, Wosu UA, Boman J, Argraves WS. Low density lipoprotein receptor-related protein-2 expression in efferent duct and epididymal epithelia: evidence in rats for its in vivo role in endocytosis of apolipoprotein J/clusterin. Biol Reprod. 1996; 55:676-83.

Morriss-Kay GM, Sokolova N. Embryonic development and pattem formation. FASEB J. 1996; 10(9):961-8.

NagDas SK, Skudlarek MD, Orgebin-Crist MC, Tulsiani DR. Biochemical alterations in the proacrosin-acrosin system during epididymal maturation of the rat spermatozoa. J Androl. 1992; 13(1):36-43.

Norden AG, Lapsley M, Igarashi T, Kelleher CL, Lee PJ, Matsuyama T, Scheinman SJ, Shiraga H, Sundin DP, Thakker RV, Unwin RJ, Verroust P, Moestrup SK. Uninary megalin deficiency implicates abnomal tubular endocytic function in Fanconi syndrome. J Am Soc Nephrol. 2002; 13:125-33. 
Nykjaer A, Fyfe JC, Kozyraki R, Leheste JR, Jacobsen C, Nielsen MS, Verroust PJ, Aminoff M, de la Chapelle A, Moestrup SK, Ray R, Gliemann J, Willnow TE, Christensen EI. Cubilin dysfunction causes abnormal metabolism of the steroid hormone 25(OH) vitamin D(3). Proc Natl Acad Sci U S A. 2001; 98:13895-900.

Odorizzi G, Trowbridge IS. Structural requirements for basolateral sorting of the human transferrin receptor in the biosynthetic and endocytic pathways of MadinDarby canine kidney cells. J Cell Biol. 1997; 137:1255-64.

Oko R, Hermo L, Chan PT, Fazel A, Bergeron JJ. The cytoplasmic droplet of rat epididymal spermatozoa contains saccular elements with Golgi characteristics. J Cell Biol. 1993; 123(4):809-21.

Olson LM, Zhou X, Schreiber JR. Cell-specific localization of apolipoprotein E messenger ribonucleic acid in the testis and epididymis of the rat. Biol Reprod. 1995; 52(5):1003-11.

Olson GE, NagDas SK, Winfrey VP. Temporal expression and localization of protein farnesyltransferase during spermiogenesis and posttesticular sperm maturation in the hamster. Mol Reprod Dev. 1997; 48(1):71-6.

Olson GE, NagDas SK, Winfrey VP. Structural differentiation of spermatozoa during post-testicular maturation. In: The Epididymis: From Molecules to Clinical Practice. Robaire B and Hinton B, Eds., Klewer Academic/Plenum Publishers, New York, 2002, pp 371-387.

Orlando RA, Exner M, Czekay RP, Yamazaki H, Saito A, Ullrich R, Kerjaschki D, Farquhar MG. Identification of the second cluster of ligand-binding repeats in megalin as a site for receptor-ligand interactions. Proc Natl Acad Sci U S A. 1997; 94(6):2368-73.

Parks JE, Hammerstedt RH. Development changes occurring in the lipids of ram epididymal spermatozoa plasma membrane. Biol Reprod. 1985; 32(3):653-68.

Pelliniemi LJ, Dym M, Gunsalus GL, Musto NA, Bardin CW, Fawcett DW. Immunocytochemical localization of androgen-binding protein in the male rat reproductive tract. Endocrinology. 1981; 108(3):925-31.

Powell LM, Wallis SC, Pease RJ, Edwards YH, Knott TJ, Scott J. A novel form of tissue-specific RNA processing produces apolipoprotein-B48 in intestine. Cell. 1987; $50(6): 831-40$. 
Rall SC Jr, Newhouse YM, Clarke HR, Weisgraber KH, McCarthy BJ, Mahley RW, Bersot TP. Type III hyperlipoproteinemia associated with apolipoprotein E phenotype E3/3. Structure and genetics of an apolipoprotein E3 variant. J Clin Invest. 1989; 83(4):1095-101.

Rambourg A, Clermont Y, Hermo L, Segretain D. Tridimensional structure of the Goigi apparatus of nonciliated epithelial cells of the ductuli efferentes in rat: an electron microscope stereoscopic study. Biol Cell. 1987; 60(2):103-15.

Ranganathan S, Knaak C, Morales CR, Argraves WS. Identification of low density lipoprotein receptor-related protein-2/megalin as an endocytic receptor for seminal vesicle secretory protein II. J Biol Chem. 1999; 274(9):5557-63.

Reid, BL and Cleland KW. The structure and function of the epididymis. I. The histology of the rat epididymis. Aust. J. Zool. 1957. 5:223-246.

Reyland ME, Gwynne JT, Forgez P, Prack MM, Williams DL. Expression of the human apolipoprotein $\mathrm{E}$ gene suppresses steroidogenesis in mouse $\mathrm{Y} 1$ adrenal cells. Proc Natl Acad Sci U S A. 1991; 88(6):2375-9.

Robaire B, Hermo L. Efferent ducts, epididymis and vas deferens: Structure, functions and their regulation. In: The Physiology of Reproduction. Knobil E and Neill J et al, Eds., Raven Press, New York, 1988, pp. 999-1080.

Romao MJ, Kolln I, Dias JM, Carvalho AL, Romero A, Varela PF, Sanz L, TopferPetersen E, Calvete JJ. Crystal structure of acidic seminal fluid protein (aSFP) at 1.9 A resolution: a bovine polypeptide of the spermadhesin family. J Mol Biol. 1997; 274(4):650-60.

Roux C, Wolf C, Mulliez N, Gaoua W, Cormier V, Chevy F, Citadelle D. Role of cholesterol in embryonic development. Am J Clin Nutr. 2000; 71 (5 Suppl):1270S-9S.

Sahali D, Mulliez N, Chatelet F, Dupuis R, Ronco P, Verroust P. Characterization of a $280-\mathrm{kD}$ protein restricted to the coated pits of the renal brush border and the epithelial cells of the yolk sac. Teratogenic effect of the specific monoclonal antibodies. J Exp Med. 1988; 167(1):213-8.

Sahali D, Mulliez N, Chatelet F, Laurent-Winter C, Citadelle D, Roux C, Ronco P, Verroust $P$. Coexpression in humans by kidney and fetal envelopes of a $280 \mathrm{kDa}-$ coated pit-restricted protein. Similarity with the murine target of teratogenic antibodies. Am J Pathol. 1992; 140(1):33-44.

Saito A, Pietromonaco S, Loo AK, Farquhar MG. Complete cloning and sequencing of rat gp330/"megalin," a distinctive member of the low density lipoprotein receptor gene family. Proc Natl Acad Sci U S A. 1994; 91:9725-9. 
Sanz L, Calvete JJ, Mann K, Gabius HJ, Topfer-Petersen E. Isolation and biochemical characterization of heparin-binding proteins from boar seminal plasma: a dual role for spermadhesins in fertilization. Mol Reprod Dev. 1993; 35(1):37-43.

Seetharam B, Alpers DH, Allen RH. Isolation and characterization of the ileal receptor for intrinsic factor-cobalamin. J Biol Chem. 1981; 256(8):3785-90.

Seetharam B, Levine JS, Ramasamy M, Alpers DH. Purification, properties, and immunochemical localization of a receptor for intrinsic factor-cobalamin complex in the rat kidney. J Biol Chem. 1988; 263(9):4443-9.

Seetharam B, Christensen EI, Moestrup SK, Hammond TG, Verroust PJ. Identification of rat yolk sac target protein of teratogenic antibodies, gp280, as intrinsic factor-cobalamin receptor. J Clin Invest. 1997; 99:2317-22.

Serre V, Robaire B. Distribution of immune cells in the epididymis of the aging Brown Norway rat is segment-specific and related to the luminal content. Biol Reprod. 1999; 61(3):705-14.

Sniderman A, Shapiro S, Marpole D, Skinner B, Teng B, Kwiterovich PO Jr. Association of coronary atherosclerosis with hyperapobetalipoproteinemia [increased protein but normal cholesterol levels in human plasma low density (beta) lipoproteins]. Proc Natl Acad Sci U S A. 1980; 77(1):604-8.

Stefansson S, Chappell DA, Argraves KM, Strickland DK, Argraves WS. Glycoprotein 330/low density lipoprotein receptor-related protein-2 mediates endocytosis of low density lipoproteins via interaction with apolipoprotein B100. J Biol Chem. 1995; 270(33):19417-21.

Sun EL, Flickinger CJ. Morphological characteristics of cells with apical nuclei in the initial segment of the adult rat epididymis. Anat Rec. 1980; 196(3):285-93.

Suzuki F. Changes in intramembranous particle distribution epididymal spermatozoa of the boar. Anat Rec. 1981; 199(3):361-76.

Suzuki F, Nagano T. Epididymal maturation of rat spermatozoa studied by thin sectioning and freeze-fracture. Biol Reprod. 1980; 22(5):1219-31.

Sylvester SR, Morales C, Oko R, Griswold MD. Localization of sulfated glycoprotein-2 (clusterin) on spermatozoa and in the reproductive tract of the male rat. Biol Reprod. 1991; 45:195-207.

Syntin P, Dacheux F, Druart X, Gatti JL, Okamura N, Dacheux JL. Characterization and identification of proteins secreted in the various regions of the adult boar epididymis. Biol Reprod. 1996; 55(5):956-74. 
Teng B, Thompson GR, Sniderman AD, Forte TM, Krauss RM, Kwiterovich PO Jr. Composition and distribution of low density lipoprotein fractions in hyperapobetalipoproteinemia, normolipidemia, and familial hypercholesterolemia. Proc Natl Acad Sci U S A. 1983; 80(21):6662-6.

Tint GS, Irons M, Elias ER, Batta AK, Frieden R, Chen TS, Salen G. Defective cholesterol biosynthesis associated with the Smith-Lemli-Opitz syndrome. N Engl J Med. 1994; 330(2):107-13.

Topfer-Petersen E, Calvete JJ. Molecular mechanisms of the interaction between sperm and the zona pellucida in mammals: studies on the pig. Int J Androl. 1995; 18 Suppl 2:20-6.

Varela PF, Romero A, Sanz L, Romao MJ, Topfer-Petersen E, Calvete JJ. The 2.4 A resolution crystal structure of boar seminal plasma PSP-I/PSP-II: a zona pellucidabinding glycoprotein heterodimer of the spermadhesin family built by a CUB domain architecture. J Mol Biol. 1997; 274(4):635-49.

Veeramachaneni DN, Amann RP. Endocytosis of androgen-binding protein, clusterin, and transferrin in the efferent ducts and epididymis of the ram. J Androl. 1991; 12(5):288-94.

Veri JP, Hermo L, Robaire B. Immunocytochemical localization of the Yf subunit of glutathione S-transferase $\mathrm{P}$ shows regional variation in the staining of epithelial cells of the testis, efferent ducts, and epididymis of the male rat. J Androl. 1993; 14(1):2344.

Vierula ME, Rankin TL, Orgebin-Crist MC. Electron microscopic immunolocalization of the 18 and 29 kilodalton secretory proteins in the mouse epididymis: evidence for differential uptake by clear cells. Microsc Res Tech. 1995; $30(1): 24-36$.

Visconti PE, Galantino-Homer H, Ning X, Moore GD, Valenzuela JP, Jorgez CJ, Alvarez JG, Kopf GS. Cholesterol efflux-mediated signal transduction in mammalian sperm. beta-cyclodextrins initiate transmembrane signaling leading to an increase in protein tyrosine phosphorylation and capacitation. J Biol Chem. 1999; 274(5):323542.

Westbrook-Case VA, Winfrey VP, Olson GE. Sorting of the domain-specific acrosomal matrix protein AM50 during spermiogenesis in the guinea pig. Dev Biol. $1995 ; 167(1): 338-49$. 
Williams SE, Ashcom JD, Argraves WS, Strickland DK. A novel mechanism for controlling the activity of alpha 2-macroglobulin receptor/low density lipoprotein receptor-related protein. Multiple regulatory sites for 39-kDa receptor-associated protein. J Biol Chem. 1992; 267(13):9035-40.

Willnow TE. The low-density lipoprotein receptor gene family: multiple roles in lipid metabolism. J Mol Med. 1999; 77(3):306-15.

Willnow TE, Goldstein JL, Orth K, Brown MS, Herz J. Low density lipoprotein receptor-related protein and gp330 bind similar ligands, including plasminogen activator-inhibitor complexes and lactoferrin, an inhibitor of chylomicron remnant clearance. J Biol Chem. 1992; 267(36):26172-80.

Willnow TE, Hilpert J, Armstrong SA, Rohlmann A, Hammer RE, Burns DK, Herz J. Defective forebrain development in mice lacking gp330/megalin. Proc Natl Acad Sci U S A. 1996; 93(16):8460-4.

Willnow TE, Nykjaer A, Herz J. Lipoprotein receptors: new roles for ancient proteins. Nat Cell Biol. 1999; 1:E157-62.

Yammani RR, Seetharam S, Seetharam B. Cubilin and megalin expression and their interaction in the rat intestine: effect of thyroidectomy. Am J Physiol Endocrinol Metab. 2001; 281(5):E900-7.

Yoshinaga K, Tanii I, Saxena DK, Toshimori K. Immunocytochemical alterations in the intra-acrosomal antigen MN7 during epididymal maturation of guinea pig spermatozoa. Cell Tissue Res. 1998; 292(2):427-33.

Young SG. Recent progress in understanding apolipoprotein B. Circulation. 1990; 82(5):1574-94.

Zhai XY, Nielsen R, Birn H, Drumm K, Mildenberger S, Freudinger R, Moestrup SK, Verroust PJ, Christensen EI, Gekle M. Cubilin- and megalin-mediated uptake of albumin in cultured proximal tubule cells of opossum kidney. Kidney Int. 2000; 58:1523-33.

Zheng G, Bachinsky DR, Stamenkovic I, Strickland DK, Brown D, Andres G, McCluskey RT. Organ distribution in rats of two members of the low-density lipoprotein receptor gene family, gp 330 and LRP/alpa $2 \mathrm{MR}$, and the receptorassociated protein (RAP). J Histochem Cytochem. 1994; 42(4):531-42.

Zheng G, Marino' M, Zhao J, McCluskey RT. Megalin (gp330): a putative endocytic receptor for thyroglobulin (Tg). Endocrinology. 1998; 139(3):1462-5.

Zubay, G. Biochemistry. Kane K, Ed., Wm. C. Brown Publishers, Dubuque, 1993. 